\title{
VLADAN DJORDJEVIĆ, THE LIFE AND WORK OF A GYMNAST, SCIENTIST, POLITICIAN, WRITER AND THE PROGENITOR OF GYMNASTICS AND THE SOKOL MOVEMENT IN SERBIA
}

\author{
Vladan Vukašinović \\ University of Belgrade, Faculty of Sport and Physical Education, Belgrade, Serbia
}

\begin{abstract}
Vladan Djordjević belonged to a generation of Belgrade Lyceum students, who later became influential representatives of science, society and politics. Tireless engagement in the social life of Belgrade and the Kingdom of Serbia, diligent performance of government and diplomatic duties, and an imposing contribution to medicine, historiography and literature put Vladan Djordjević among the most respected figures of Serbian history. Beside achieving much in the establishment of socio-cultural, scientific and political life of Serbia, he also contributed greatly to the development of physical culture in the Kingdom of Serbia at the end of the $19^{\text {th }}$ and the beginning of the $20^{\text {th }}$ century. As a student of the Belgrade Lyceum, while practising gymnastics and martial arts, Djordjević became a great aficionado of physical exercising and gained insight into its importance for health and strengthening of spirit. Djordjević could not forget this beginning of organised gymnastics exercising and so, twenty-four years after finishing his studies, as a distinguished physician and the head of the Medical Department of the Serbian Ministry of the Interior, he became the progenitor of the idea to set up "a great gymnastic society in Belgrade with branches all over Serbia". The development of gymnastics in Serbia allowed the spread of the Sokol Movement and the advent of modern sport in this country. The goal of this paper is to apply the historical method in the study of authentic documents from 1895, 1908, 1910, 1925-27, 1938, etc., which are mostly unknown and unavailable to the wider and expert public and which illuminate the various contributions of Dr Vladan Djordjević, particularly in the domain of physical culture.
\end{abstract}

Key words: VLADAN DJORDJEVIĆ / PHYSICAL CULTURE / MEDICINE / LITERATURE / HISTORY / POLITICS / SERBIA

\section{THE LIFE OF VLADAN DJORDJEVIĆ - IMMORTAL KNOWLEDGE, DEEDS AND VIRTUES}

Dr Vladan Djordjević, a prominent figure from Serbian history, left a lasting mark on the scientific, cultural, social and political life of Serbia at the end of the $19^{\text {th }}$ and the beginning of the $20^{\text {th }}$ century through his intellectual and organisational work. This intellectual and physician, known even outside Serbia, left behind him a deep imprint, valuable works and ideas with which he had changed Serbia for better and created public life in its capital Belgrade. An erudite and an avant-garde, impulsive and persistent person, he modernised and contributed to medicine, military, politics, diplomacy, cultural and social life, literary and historical publishing, education, sport..., to every field where he found himself and which enticed him to work in it. He was tireless in any labour he undertook, determined, innovative, modern and significant for the advancement of both the Serbian society and the state.

Numerous data reveal Djordjevićs various interests and organisational and labour potentials in a number of activities which he devoted himself to. What has been less researched is his contribution to the development of physical culture, i.e. physical exercising, and civilian and school gymnastics, which would lead to the advent of modern sport and the Sokol Movement in the Kingdom of Serbia at the end of the $19^{\text {th }}$ and the beginning of the $20^{\text {th }}$ century. The goal of this paper is to confirm the aforementioned statement of Dr Djordjevićs excellence with facts 
obtained through the historical method. Besides this, the goal of the paper is also to serve as an unpretentious contribution to the study of works of famous and historically affirmed Serbian intellectuals.

\section{THE ERUDITION AND AMBITION OD THE YOUNG IPOKRAT}

Vladan Djordjević was born in Belgrade on 21 November 1844 in Gospodarska St. (today, Vasina St.) in an Aromanian family. His father Djordje Djordjević, a medic in the Serbian army, and later a lieutenant, originally from Epirus in Greece, and his mother Marija Leko, from an influential Belgrade Aromanian family, wanted their second child to become a physician and so gave him the name Ipokrat, after Hippocrates. The Djordjević family suffered tragedy with their offspring. In a short period, they lost three children. When he was seven Ipokrat also lost his mother, who died not long after giving birth. Ipokrat's father took him out of the Greek school and moved with his entire family to Sarajevo to start a pharmacy business. There Ipokrat graduated from the Serbian school with excellent marks. In order that he could continue his studies, the family returned to Belgrade. Having shown a considerable knowledge, he was immediately accepted into the second year of Belgrade's First Male High School (Djordjević, 1927).

When he enrolled at the Belgrade Lyceum in 1862 (the first college in Serbia), at the suggestion of the dean, the famous philologist Djura Daničić, Ipokrat changed his name into a more Serbian one - Vladan, which is a translation of the second part of his given name: Ipo-krat (in Greek kratein means to rule). Although he was already considered a student of linguistics and a future writer, after the first year at the Lyceum the dilemma over the continuance of his education was resolved by his professors. Estimating his capabilities at the Department of Natural Sciences, they decided that he should study medicine, and the greatest influence on this had had another professor of great repute - Josif Pančić (Subotić, 1910).

During his years at the Lyceum Djordjević was a member of The Company for Gymnastics and Martial Arts, operating within The Painting School, founded by Stevan Todorović in 1857. In his private institute Todorović taught drawing, painting, singing and acting, but since he was a great gymnastics and fencing enthusiast, he taught the Lyceum students these skills as well (Vukašinović, 2017). Despite its conservative stance, the Company attracted the student population, particularly because of the support it enjoyed from Prince Mihailo Obrenović. It was a time of patriotic exuberance directed at cultural changes and social advancement of the Principality of Serbia, as well as at the completion of the liberation from the Ottoman yoke.

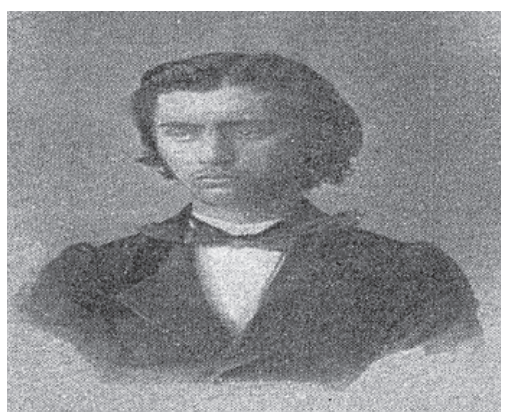

Photo 1. Vladan Djordjević as a high school student

Ipokrat Vladan Djordjević exercised in The Painting School together with other Lyceum students who would one day become well-known politicians and scientists: Miloš S. Milojević, Milan Kujundžić, Čeda Mijatović, Ljubomir Kaljević, Steva Popović - Crni, Andra Nikolić (Petrović, V. J., 1983). "Šćeva", as the young physical exercising enthusiasts had nicknamed their teacher Todorović, besides urging his students to exercise, he also endeavoured to enlighten and educate them in the patriotic spirit (ibid.). Djordjević was not only gifted for gymnastics and fencing, but he also started to exhibit interest in literature and to write dramatic works with great enthusiasm when he was still young. He studied history and languages, translated, and in the fifth class he was already reading novels and magazines in German; he also studied to paint and play the piano, and he acted in theatres (Djordjević, 1927). It can be said that he was well known for his numerous interests and the desire to improve himself.

\section{DR VLADAN DJORDJEVIĆ - PROFESSIONAL DEDICATION, IN THE SERVICE OF THE SERBIAN PEOPLE}

In autumn 1863 Vladan Djordjević was sent at the government's expense to study at a prestigious medical school in Vienna. He was taught by renowned medicine professors such as Hirtl, Brücke, Rokitansky, Škoda, Hebra, Sigmund, and the famous surgery professor Theodor Billroth, who would proclaim 
Vladan his most gifted student. Djordjević confirmed this when he brilliantly defended his graduation thesis at the end of 1868, and in January 1869 he was granted the title of $\mathrm{MD}$, while only five months later he received the title of surgeon, which was followed by a magister degree in obstetrics (Godišnjak Srpske kraljevske akademije 8, 1895 - Almanac of the Serbian Royal Academy, in the following text "Godišnjak SKA 8", 1895). During his studies and a two-year specialisation in Vienna, he acquired a considerable skill in surgery and he adopted Prussian punctuality, discipline and work organisation under the great influence of Professor Billroth. Even though he had started a practice at a surgical-gynaecological clinic in Prague, ambitious Djordjević returned to Vienna to specialise in surgery (1869-1871). He attracted attention early with his first scientific papers, which he wrote in German and then translated into Serbian for "The Serbian Learned Society". At the Vienna clinic, he gained a specialist diploma of a surgeon-operator.

To gain further specialisation "in war surgery techniques", he asked from the Serbian government to allow him to join the Prussian medical corps during the Franco-Prussian War. In a large war hospital in Frankfurt Djordjević distinguished himself as a practising physician and the head of one ward, and for his contributions, he was granted the rank of reserve medical lieutenant (Subotić, 1910). Djordjevićs ambition, professional curiosity and results of his work could not go unnoticed. Though young, he was soon elected into the position of a permanent member of the "Serbian Learned Society" in 1869, "Society of Physicians" in 1870 and the Anthropological Society in Vienna in 1871 (Godišnjak SKA 8, 1895).

After eight years, Djordjević returned to Serbia in July 1871 as the first Serbian surgeon. He opened a medical practice in Belgrade and for a while, he worked as a private physician and operator. He was soon known as somebody who cared for the well-being of his people and treated the poor for free, helping them with financial donations. In public gatherings and lectures, he suggested the establishment of a poor people's home, hospitals for poor children, a pavilion for poor pregnant women, schools for deaf and blind children. He submitted a request to the Ministry of the Interior to be allowed to treat the poor for free and thus repay the country for the scholarship he had received to study abroad. Instead of receiving a response, five months later he was appointed a military physician of the second class and the chief of the surgical ward at the Belgrade General hospital (1871) by Prince Milan Obrenović. Besides holding this function, he also taught the first hospital service courses and he was the first professor of military surgery in the Artillery School, which would later become the Military Academy (Subotić, 1910). In 1872 he established "The Serbian Medical Association".

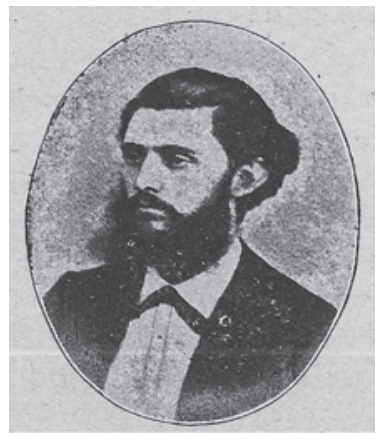

Photo 2. Dr Vladan Djordjević, the founder of the Serbian Medical Association, 1872

His successful medical career would, after two years, bring him to a life turning point. In 1873 he became the personal physician of the 18-year-old Prince Milan Obrenović (Jovanović, 1926). This had a decisive impact on further developments in Djordjevićs's career, his political affiliations and the fate of his family. In the Prince, he saw a ruler with a clear vision of modern and progressive Serbia, which Milan Obrenović did later manifest in his ability and wisdom regarding the foreign and internal policy, with his contributions to Serbia gaining independence and international recognition, the country's territorial expansion as well as modernisation of the government institutions. During his early years of service, he had tremendous influence over the young Prince, and for that reason, many of his initiatives were realised in a short time period. With the Prince's both moral and material support he initiated the founding and the development of important institutions, such as the civilian and the military medical services, Serbian Medical Society and the Red Cross of Serbia. Over the seventeen years of service to the Obrenović crown (on multiple occasions), as a physician and later a government official, he shared the ups and downs of the country and several times he suffered from the Obrenović dynasty turning their backs on him or using him for their own ends.

During the first six years, he had spent at the royal court he had often suffered unpleasantness due to Prince Milan's unpredictable and difficult temper, but also due to Princess Natalia's animosity, which was the result of his honesty. The service at the court, with its intrigues and affairs, was a great burden to him. When he left the court he spent some ten years managing the military medical service in both Serbian-Turkish Wars (1876-1878), and in the Serb-Bulgarian War (1885-1886), as well as the civilian med- 
ical service during the peacetime. For the successful organisation of the military medical service he was supposed to be promoted to the rank of colonel after the First Serbian-Turkish War, but Princess Natalia tore the corresponding decree of Prince Milan. Vladan resigned, but the Prince did not accept it and decorated him with the Order of the Cross of Takovo, which up to that point only the Russian general Mikhail Chernyayev had received. In the Serb-Bulgarian War, he was moved back from the reserve into the active service, and that was when he received the rank of medical colonel. Until then, the highest rank a physician could have in the Serbian army was that of a major (Subotić, 1910).

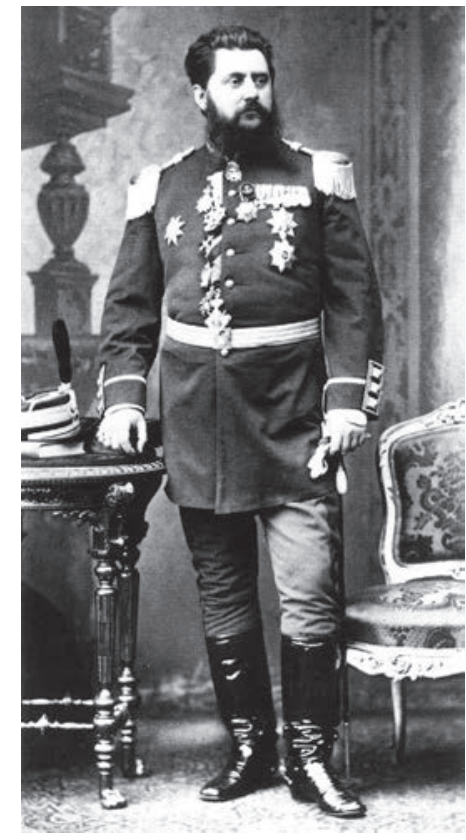

Photo 3. Dr Vladan Djordjević, chief of the Military medical service

\section{VLADAN DJORDJEVIĆ - INEXHAUSTIBLE STRENGTH AND CONSISTENCY IN PRINCIPLES}

Dr Djordjević started participating in the Serbian politics in 1883, even though until then he was politically independent. He propagated progressive ideas, the cult of science and the enlightenment of the people. He spoke of being "an Obrenović supporter through his father", but that the idea close to his heart was that of "the spirit of enlightenment", i.e. the faith in science and its power to bring progress and understanding, since the "enlightenment of the people is the initiator of historical processes" (Rajić, 2005). He opposed the involvement of the masses in the politics, seeing the dangers brought by radicalism. His fierce temper and bitter disputes with the leaders of political parties, and even with the members of the royal family, caused him many troubles.

When he could no longer be dealt with, Dr Djordjević was made the mayor of Belgrade in 1884, and the first thing he did was get rid of bureaucrats. During his two years as mayor, he successfully dealt with the challenges of running a town. The municipality employees respected him even though he was strict and couldn't tolerate laziness. Such traits he referred to as "the oriental decadence". Due to his life motto "Laboremus" ("let's work" in Latin), and a long-discussed and quoted statement of his, from a lecture he gave, which was then printed in the magazine "Otadžbina" - "Serbian enthusiasm is like a brass stove, which heats up quickly, but cools just as fast", he was considered an atypical resident of the Balkans (Subotić, 1910). On one occasion he kicked out of his office a representative of a cement factory and revealed that the man had tried to bribe him. True to his principles, he resigned from the mayor's office because of a dispute with the Minister of the Interior over the introduction of an excise duty, but only after he received the vote of confidence from the municipal assembly (Archives of Serbia, the personal fund of Vladan Djordjević, 1969). Dr Djordjević knew quite well how to cause disturbances in the inert milieu of Belgrade of that time.

Djordjević considered telling truth very important, and occasionally he would be highly critical in his writings and speeches about King Milan's oversights and political moves which weakened the country and slowed its growth. King Milan didn't appreciate such criticisms. Their first major dispute occurred when Djordjević called for the King and his ministers to be held accountable for Serbia's defeat at the battle of Slivnitsa in November 1885, during the Serb-Bulgarian War. In "Otadžbina" he wrote "the naked and bitter" truth about the political and military conduct of the war (1887). King Milan, feeling offended, personally wrote the lawsuit against him, demanding that he be sent to prison, but the court proclaimed him innocent. Several months later, the King had to comply with the decision that Djordjević be made the Minister of Education and Church Affairs and the Minister of Economy (Godišnjak SKA 8, 1895). However, even after this, he was ill-favoured by the King because of him printing "the true history of Slivnitsa". That same year, with his own hand, the King erased Djordjevićs name from the list of candidates for the first Serbian academics.

Djordjević's family faced great trouble when King Milan abdicated too early in 1889. Vladan Djordjević found the relinquishing of the throne and putting the 
state in the care of the underage Prince Aleksandar and the Regency in the climate of unstable political relations in the country as irresponsible and selfish. For that reason, several days after the abdication, in October 1889, he was sent into early retirement (for the first time) (ibid.). With King Milan leaving the country Djordjević withdrew from the public life, but only for a short while. The Obrenović dynasty remembered him again because they need him.

Beside numerous duties that he performed, Dr Djordjević, being a great aficionado of physical exercising, founded in 1881 The Belgrade Society for Gymnastics and Martial Arts, with the idea to use this "central gymnastic society to establish similar ones in every town for the purpose of improving health and the physical strength of the people". This was a turning point for the development of gymnastics in other Serbian towns, including the Sokol Movement and certain sports soon after (Vukašinović, 2016, 2016a).

In 1891 Djordjević accepted the offer from the Regency to become the Serbian ambassador to the King of Greece in Athens. For three years he successfully worked on improving the friendship between Serbia and Greece, until January 1894, when, due to budget restrictions, he was sent into retirement again. Three months later he was appointed as the Serbian ambassador in Constantinople (in April 1894), an important and unpopular centre of the Serbian foreign policy. In difficult conditions imposed by the oriental spirit of cunning diplomats, he successfully struggled for the vital Serbian interests (Jovanović, 1925, 1929).

After King Milan returned from exile and young King Aleksandar removed from power the Radical Party led government, Djordjević was invited back to Serbia to form a new government. As the Prime Minister and the Minister of Foreign Affairs, he had a difficult task of serving two kings at the same time, both of whom wielded significant influence (the former king was granted the position of the supreme commander of the active military). He resigned when, during his term in office, an unsuccessful assassination of King Milan took place in 1899 in Belgrade. However, when the former king accused him of running away when it was most difficult, he withdrew his resignation (Ćorović, 2010; Jovanović, 1935).

Due to the dissatisfaction of the officers with the "unsuitable" engagement of King Aleksandar and the widow Draga Mašin, Djordjević tried in various ways to dissuade the young King from such a move and that was how they ended up in a bitter dispute. After the wedding, Djordjević resigned together with other ministers (1900) and found himself in another troublesome situation, thus putting himself and his family in serious danger. The daily press received orders from the palace to mercilessly attack him. His three years as the head of the government were called "Vladanism" and it took some time for the public to realise that "Vladanism and other widespread beliefs were myths corresponding little to the reality, because it had been the regime of kings Milan and Aleksandar that had held the power, not Vladan Djordjević" (Jovanović, 1935).

In an attempt to completely humiliate Djordjević, King Aleksandar sent him into retirement illegally (in 1900 - the third retirement). Pension, which he was owed because of his involvement in the government, was taken from him, along with the rank of a colonel. Disappointed, Vladan Djordjević left for Vienna, into a "voluntary exile", as he had called it himself, and there he spent six months writing for a number of Viennese, and one Berliner newspaper, until the government of Serbia annulled the King's illegal decree (Godišnjak SKA 21, 1908). After the bloody May Coup (Belgrade, 29 May 1903), when the royal couple were murdered, he spent two more years in Vienna, and then returned to Serbia. After that, as a retired former Prime Minister, he devoted himself to literary work, mostly writing history (in German and Serbian). In his memoirs titled "The End of a Dynasty", he described some ministers in such a manner that he ended up in prison under the charges of disclosing government secrets (1906). However, the true reason for this was him writing that "the Queen of England couldn't receive King Aleksandar". He spent six months in Belgrade's "Glavnjača" prison because he did not want to beg for mercy that had been offered to him (ibid.). In the book "A Minister in Jail", he wrote the following about his intention to go to Vienna after serving his sentence: "I'm leaving to take a breath in a country with some semblance of the rule of law, where patriotism is not a crime." During the Great War, he also ended up imprisoned, from 1915 until 1918, not far away from Vienna. Upon his return, he lived in Belgrade and occasionally visited Dubrovnik.

In his 86-year-long, eventful, and not at all easy life, Vladan Djordjević witnessed six wars, changes of constitutions, regimes, dynasties, and was a witness of numerous major historical events. His winding life path, closely tied to the Obrenović dynasty, brought him many things - renown, honour, high positions, but also sacrifices, conflicts, personal attacks, three retirements and two imprisonments. His three years younger German wife, Paulina Britner, love from his student days, gave birth to fifteen children, but only four survived. His eldest son Milan, a captain of the first class and a lawyer, died fighting in the first lines during the liberation of Dubrovnik from Austria-Hungary in 1918. His second son, Aleksandar, lived in Paris, where Djordjevićs descendants can be 
found even today. His two daughters have left numerous descendants in Deroko and Vlastari families.

\section{VLADAN DJORDJEVIĆ, AN ERUDITE PLEDGED TO INCREASING THE PROSPERITY OF THE SERBIAN PEOPLE AND SOCIETY}

\section{Medicine, military and civilian medical service}

Tremendous contributions to the development of Serbian medicine and military and civilian medical services are ascribed to Dr Vladan Djordjević. Because of his significant experience from working in different institutions, including internship in prestigious clinics, his private practise and involvement in military and civilian medical services, he had an encompassing and competent insight into the problems and needs of the Serbian society in the domain of health care and disease prevention, which were in their infancy in Serbia at that time.

The greatest credit for gathering 15 physicians from six different ethnic groups and the founding of the "Serbian Medical Association" (1872) goes to Djordjević. For three years he was the Society's first secretary, then he spent four years as vice president (1886-1889) and two years as president (1890-1891). He started the journal "Srpski arhiv za celokupno lekarstvo" - "Serbian Archive for All of Medicine" (1874) and worked on editing, translating and publishing its first issues. He had started the "Archive" with the intention that all Serbian physicians should be able to follow the new developments in medicine no matter where they lived. Thanks to the favourable position he enjoyed with King Milan, Djordjević ensured government support for the Association and thus the free publishing of the journal (Godišnjak SKA 8, 1995).

Vladan Djordjević also significantly contributed to the founding of the "Serbian Society of the Red Cross" (1876). He gathered several reputable individuals in the Principality of Serbia to serve as members of the managing board. The first task of the newly established Society was to take care of refugees coming to Serbia due to the Herzegovina Uprising. Thanks to his influence the foundations of the Society were laid in the first year of its existence and it was also formally recognised by the International Committee of the Red Cross. The work of the Society was well organised from the beginning - directed at collecting the financial and material aid, organising of hospitals, employing of physicians, training of volunteers, acquiring of medical equipment and providing assistance to the military medical service (Subotić, 1910).

Dr Djordjević worked in the military medical service in all the wars Serbia had fought at that time. In the First Serbian-Turkish War (1876) he was the chief of the medical service of the Morava-Timok Army. In the Second Serbian-Turkish War (18771878), and later in the Serb-Bulgarian War (1885), he was the chief of the medical service within the high command of the Serbian military. In these situations, he showed extraordinary organisational abilities. He founded and was the first manager of the Niš Military Hospital (January 1878), also known as "Moravian Military Hospital". Due to the efforts of Djordjević, the organisation of the Niš hospital was established, and at that time it was the central institution of the military medical service in the south and east of Serbia, which would later, during the Balkan Wars and the Great War, prove to be of major significance (Savić, 2014).

While teaching to the medical company of the Serbian army at the Belgrade Military Hospital and later giving lectures on army hygiene at the Military Academy, he wrote two textbooks - "Hospital Service" and "The Principles of Army Hygiene" (1874). He was awarded for writing the book "Manual for the Military Medical Service of the Standing and People's Army in Peace and War Times" (1876). He put into motion the establishment of the military medical corps for the Serbian army. He initiated numerous debates on the reform of the medical profession (1879-1881) (Subotić, 1910).

As the chief of the civilian medical service of Serbia (from 1879), he started and successfully reorganised the medical service in 1881. To implement a wide reform, he spent several years carrying out correspondence with medicine professors from universities in Paris, Vienna, Stockholm and Geneva. Numerous letters testifying to this have been preserved and they contain the highest praises of European experts regarding the reform (Archives of Serbia, Vladan Djordjević fund).

Djordjević was the author of laws and books on health care. His extraordinary speech, given in the National Assembly, on infectious and animal diseases, child delivery hygiene, infant care, unqualified mid-wives, quality nutrition, prejudices and customs 
detrimental to the health of the uneducated populace, and other things, is rather famous. This speech accelerated the passing of the first Law on health care in Serbia (in 1881 - it was referred to as "Vladan's health care law"). Not long after, he published several books pertaining to this area: "A Corpus of Laws and Regulations on Health Care (official comments, instructions and rules on how to apply these laws) and others. He also participated in the writing of veterinary legislation and formulating of the terms of the veterinary convention between Serbia and Austria-Hungary, as well as the founding of the "National Health Care Fund". He also started running a weekly on hygiene - "Public Health" (1881), which he edited until 1884. As the chief of the civilian medical service, he represented Serbia at congresses on hygiene in Geneva, Turin and Vienna (Subotić, 1910).

Detailed records from the meetings of the "Serbian Medical Society" show that Vladan Djordjević wrote about and referred to various surgical procedures he performed in Belgrade's Town and Military hospitals, and sometimes even in private homes. He translated most of his works on performing surgery (Čolović, 2007). Even in his seventies, he was still socially active and he participated in the work of the "Serbian Medical Association", where he gave lectures and contributed to the establishment of the Department for the History of Medicine at University of Belgrade's Faculty of Medicine (1920). This department was, however, abolished six years after his death.

\section{Social appointments, politics, diplomacy}

Vladan Djordjević, though a conservative Obrenović supporter, was an avant-garde person. A great optimist and fighter, devoted to the development of his country, while also knowledgeable about the achievements of more advanced societies, had a lot of work to do on changing the social and political life of the Kingdom of Serbia. In his youth, as a government scholarship holder, a Republican in his beliefs and secretary of the organisation "United Serbian Youth" he advocated "the improvement of education and people's awareness" and "the equality of women with men" among the young people. Due to the "more open" ideas which he had expressed at the Moscow Slavic Congress, where he opposed Russian becoming the Slavic lingua franca, the Minister of Education took his scholarship away, which King Milan later returned (Subotić, 1910). Djordjević changed his political beliefs, from being a liberal during his student days to becoming an Obrenović loyal- ist due to the influence of King Milan from whom he had great expectations. For that loyalty, he was with reason considered a monarchist.

By the decree of King Milan, Djordjvić was appointed the mayor of Belgrade (1884-1885). After reorganising administration, he set the foundations for the planning and construction of infrastructure in Belgrade: he initiated the construction of the water supply system and sewers, the modernisation of street lighting by introducing gas lamps, then he started the refurbishment of the Sava Quay (Savamala), the tracing of the tram lines, the paving of streets; he set up a market on Cvetni trg, planted 1,000 trees, moved the town cemetery from Tašmajdan to a large estate of his, which he gave to Belgrade as a gift (nowadays Belgrade's New Cemetery, then known as "Vladanovac"), he increased the municipal revenue by introducing excise taxes; he also introduced the planning of financial assets for health care affairs in the municipal and government budgets, started the work on the comprehensive project "Belgrade Municipal Affairs", and introduced harsh fines for those who broke sanitary regulations (1-4, 1884-1885) (Archives of Serbia, Vladan Djordjević fund, 1969; Subotić, 1910).

Whenever anarchy and chaos threatened the country he would criticise the Radical Party in the Progressive Party paper "Videlo" for "poisoning the people" with its demagogy, which would eventually lead to the Timok Rebellion (1883). He emphasised the need for the legal order to be defended. After the defeat of the Timok Rebellion, the Progressive Party appointed him (for the first time) a member of parliament. As an MP he remained a defender of the crown and its rights, but was also an advocate of civil and political liberties and he called for the institutions to be rid of corruption (Rajić, 2005). Djordjevićs fiery temperament, "sharp tongue" and strong words of his newspaper articles, as well as debates with the political party leaders, and even with the members of the Obrenović dynasty, caused him much unpleasantness. He spoke rather harshly against the socialists, radicals, progressives and liberals and for that reason was a thorn in the eye to many. It was being said that "Dr Vladan cuts his opponents mercilessly, with both knife and his tongue". He called for regular (non-violent) political trends and criticised Svetozar Marković for his ideas about causing a coup, thinking of them as wrong and harmful. He wrote that it was better to gain "true civil liberties" through legal means and the freedom of speech and the press. He contributed to the passing of numerous tax reforms and useful laws. $\mathrm{He}$ proposed the construction of a railway network 
for the purpose of development of the country and its society. He called for independent courts to be established and the governance, education and military to be better regulated. He could not tolerate inert state of government institutions, and because of that he wrote an article in the paper "Otadžbina" titled "Comparison of Several Government Budgets" (1891), demanding that true government budget be discussed in the National Assembly (Archives of Serbia, Vladan Djordjević fund, 1969; Godišnjak SKA 21, 1908).

In 1888 he was appointed Minister of Education and Church Affairs and a representative of the Minister of Economy. After that, his diplomatic career started. First, he was the Serbian ambassador in Athens from 1891, and in 1894 he was sent to Constantinople (1894-1897). During that time governments kept changing in Serbia - Radical, neutralist and Progressive, but each one was satisfied with his diplomatic work (Jovanović, 1925; Rajić, 2005). Thanks to his "tireless manoeuvring" and personal charisma he managed to build good relations with Russian diplomats and Sultan Abdul Hamid II, which was helpful in resolving disputes with Bulgaria and Greece. It was then that the position of the Serbian populace and the Serbian Orthodox Church in the Ottoman-controlled Old Serbia (Rascia, Kosovo, Metohija and Vardar Macedonia) and Macedonia (Thessaloniki and Manastir vilayets) was improved, by the Ecumenical Patriarch and Sublime Porte approving the appointment of Serbian bishops (in Eparchies of Raška and Prizren and Skopje) and opening of Serbian schools (Jovanović, 1929). After that, he was appointed as the Prime Minister and Minister of Foreign Affairs (1897-1900). It is well known that his "neutralist" government worked on the economic and military strengthening of Serbia, mitigating of fierce inter-party conflicts and enacting of a large number of laws.

Interesting information is that Djordjević had influenced King Aleksandar Obrenović to visit the Hilandar monastery at Mt. Athos upon his return from Constantinople and Greece (1894). Over the course of this visit, the first visit of a Serbian monarch since the Middle Ages, the ownership dispute with Bulgarians over the monastery was finally resolved by the King buying off the monastery's debts. In return, the Hilandar monks gifted him with priceless national treasures - The Gospel of Miroslav, the original monastery founding charter issued by the Grand Prince
Stefan Nemanja and several valuable manuscripts (Lukić, 2010).

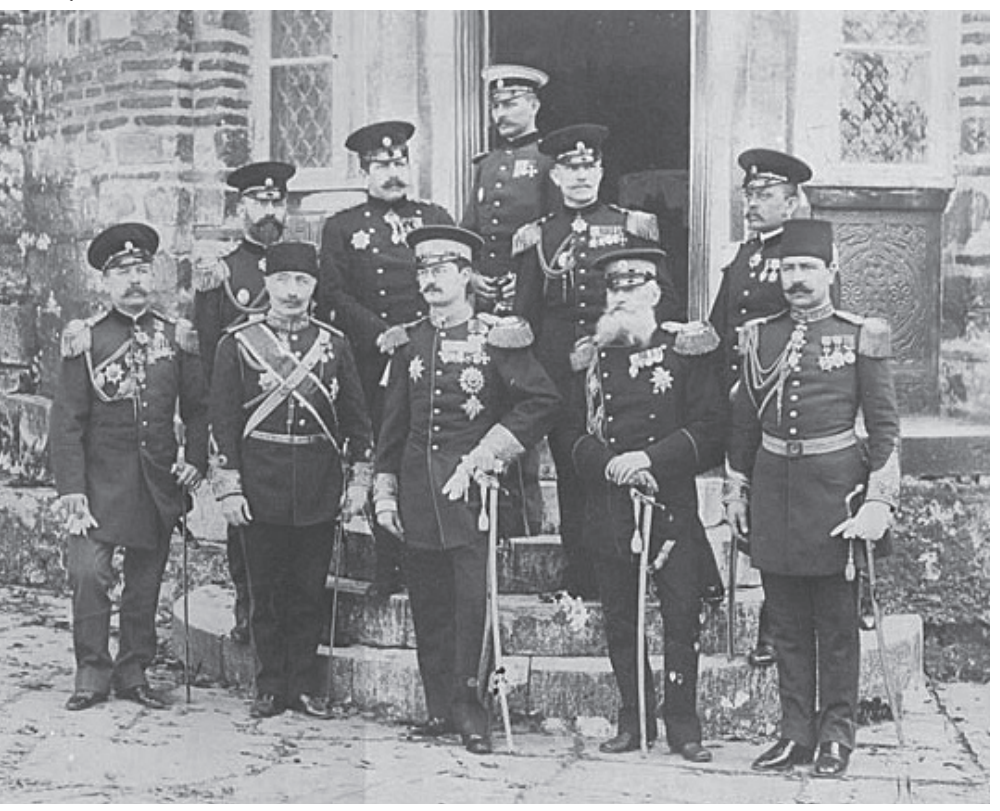

Photo 4. King Aleksandar Obrenović, in front of the Hilandar monastery church, 1894

\section{Publishing, literature and history}

Djordjević was considered one of the most prolific Serbian authors even during his life. He was appreciated because of his large literary opus, and the energy which he invested into his novels, short stories, dramas, novellas and poems. He published his first short story when he was in the second year of high school (1860), and after that, he wrote ceaselessly. In the sixth year, he received royalties for dramas, tragedies, comedies and translations. When he was a university student he had already had 29 literary works published in magazines "Danica", "Vidovdan", "Vila", etc. (Jovanović, 1925; Godišnjak SKA 8, 1895).

He actively participated in the work of the literary society "Zora", and he initiated its merger with the society "Srbijanac". That was how "The United Serbian Youth" was formed in Novi Sad in 1866, and its membership consisted of people from Austria-Hungary and Serbia. When he was chosen as the organisation's first secretary and editor of books aimed at the younger audience he immediately started a translation department whose task was the translation of the best works of world literature so as to bring about the enlightenment of the common people (Subotić, 1910).

Djordjevićs varied and rich biography represents a valuable source for the seven decades of Serbian history which cover his life. Critiques from Europe- 
an literary circles regarding the majority of Djordjevićs novels were rather positive. These works were described as "documentary, artistic, objective, poetic, thorough, and they show great knowledge of Serbian history and oriental relations, and are written in excellent German". He wrote in many languages, and some of his three-volume novels exceed 1,500 pages. He translated into Serbian from Russian, French, German and Greek (Tolstoy's "Anna Karenina", Moliere's "The Miser", then Balzac, Berthold Auerbach, Goldoni and others) (ibid.). He also contributed to Serbian and Greek cultures coming together: he wrote a great study about the Serbian and Greek representatives of the Enlightenment - Dositej Obradović and Adamantios Korais ("Grčka i srpska prosveta" - The Greek and Serbian Enlightenment, 1896); he translated into Greek some short stories by the Serbian author and his best man Dr Laza K. Lazarević, and wrote with great interest about the contemporary Greek culture. Besides some 180 papers on medicine, history and literature, a considerable collection of manuscripts of his scientific and literary works was preserved, together with orations, polemics, articles, lectures, feuilletons, memoirs, diplomatic reports, proposed laws, letters and reviews published in various Serbian and international weekly and daily newspapers, as well as some unpublished ("Srbija i Rusi" - Serbia and Russians...) (Godišnjak SKA 8, 1895; Slapšik, 1988).

The list of Djordjevićs most important works includes: "The History of the Serbian Military Medical Service", 1-4 (1879-1886), "The End of a Dynasty", 1-3 (1897-1900), "Serbia at the Congress of Berlin" (1890), "Serbian-Turkish War", 1-2 (1907), "The History of the Serbo-Bulgarian War", 1-2 (1908, the Ministry of Defence bought 200 copies, stating that it was "the true history of the war from the perspective of the Chief of Staff HQ"), "Golgotha” (1909, 31 extraordinary reviews), "A Minister in Jail" (1909), "Serbica" (1909, a historical study based on a collection of 800 documents about the history of Serbia and Montenegro from 1804 to 1815 - currently kept in the Serbian Academy of Sciences and Arts), "Albanesen und die Grossmachte" (1913, Albanians and the Great Powers, author's note), "Emperor Dušan", 1-3 (19191920), "Montenegro and Austria 1814-1894" (1924), "Memories", 1-5 (1927)1 (Subotić, 1910; Djordjević, 1909).

"Djordjević published and edited the literary magazine "Otadžbina" (1875-1892), one of the most 1 TN: The titles of all of these works were translated from Serbian
into English. significant literary magazines in the $19^{\text {th }}$ century Serbia, where the works of some of the most important authors of 1880 s and 1890s were published (Slapšak, 1988). He financed the magazine with his own money, considering it a matter of honour and an opportunity for truthful and educational content to reach the readers without censorship. The header of each issue's front page contained the lyrics from Djura Jakšićss famed poem "Otadžbina" (Fatherland in English) to awaken pride in every Serb reader, and Djordjević was particularly fond of this. After having a rather enjoyable meal which Djordjević had paid for him, Jakšić, who also had a sharp tongue like Vladan, wrote the poem in the "Dardaneli" kafana (A traditional Serbian restaurant, now the location of Palace Albanija), from his soul and without making any later corrections. On a torn piece of a newspaper, he wrote: "I ovaj kamen zemlje Srbije, što preteć suncu dere kroz oblak... - which in English means "And this rock of Serbia, which despite the Sun breaches the clouds..." (Lukić, 2010).

\section{FROM GYMNASTICS AND MARTIAL ARTS TO CIVIL AND NATIONAL VIRTUES THROUGH EXERCISING}

The 1881-1891 period in Djordjevićs life was rather busy. He worked on reorganising medical service, compiling of laws on health care and animal care. He participated in the tumultuous political life as an MP and kept proposing tax reforms and changes in the government institutions. He successfully managed Belgrade as its mayor and found time to write three multi-volume works from the domains of medicine and history, all the while suffering blows with his family from King Milan Obrenović. He even managed to establish civilian gymnastic societies throughout Serbia. In October 1881 he initiated the founding of The Belgrade Society for Gymnastics and Martial Arts (the modern day Sokol Society Belgrade Matica) which would soon receive great support and assistance from the people, philanthropists and Ministries of Education, the Interior and Defence. With his friends, former Lyceum students and well-regarded individuals in important positions and thanks to his long-term affection towards gymnastics and his stunning physical strength, he successfully worked on improving the reputation of the Society and helped the founding of other gymnastic societies and training of gymnastics teachers (Vukašinović, 2016). 


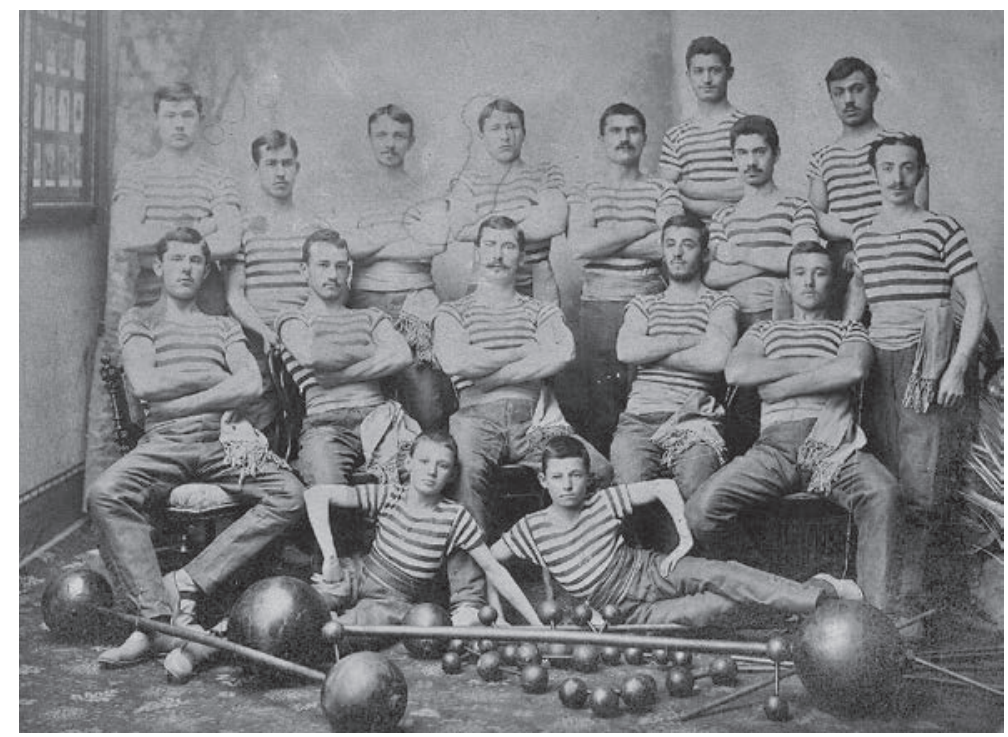

Photo 5. Belgrade Society for Gymnastics and Martial Arts, 1889

ty by appealing in a letter to the Minister of the Interior Milutin Garašanin. Garašanin did not require much convincing because the positive news about the Sokol Movement and sports had been reaching Serbia more and more often, and for that reason, he gave support to the initiative for a large gymnastic society to be established, with branches throughout the entire Kingdom of Serbia. He sent a lengthy letter to Stojan Novaković, the Minister of Education and Church Affairs. The contents and the style of the letter signed by Garašanin clearly indicate that the author had actually been the dedicated and systematic Dr Vladan Djordjević, considering the thoroughness in depicting the terrible state of health of the young people and the rest of the populace. Djordjević also listed numerous suggestions on how to solve insti-

\section{Physical exercising, physical education in schools and sports}

As a Lyceum student, young Ipokrat fell in love with gymnastics and saw how important it was for health and the development of physical and intellectual abilities. Vladan never forgot this beginning of organised gymnastics practising and the enthusiasm of the Lyceum students with Stevan Todorvić's pedagogical skill to teach them both art and sports in his Painting School.

Some twenty-five years later, as a respected surgeon, military physician and the chief of the civilian and medical services, Dr Vladan Djordjević started spreading the idea about founding a gymnastic socie-

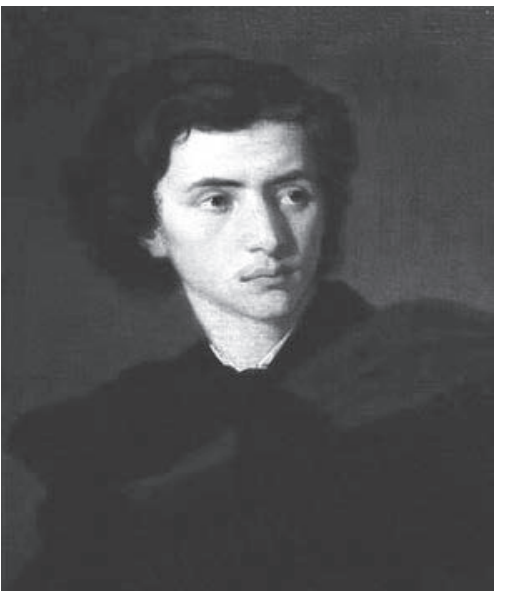

Photo 6. Ipokrat Vladan Djordjević, an oil painting by Stevan Todorović

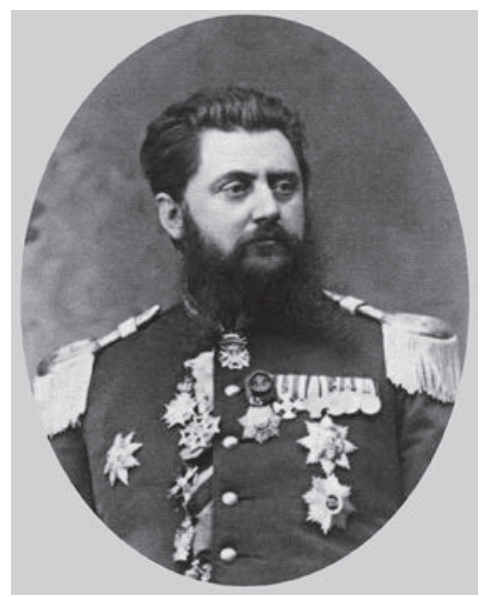

Photo 7. Medical colonel Dr Vladan Djordjević tutional, material and personnel issues regarding the introduction of school and civilian gymnastics:

"I know quite well that until now gymnastics could not receive as much attention in our schools as the physical development deserves, according to the conviction of all contemporary pedagogues and physicians, only because for this subject we have had almost no qualified personnel. But, it is for that reason that I believe that it is finally time to think about the way how to get more good gymnastics teachers..."

"There is irrefutable evidence that our people are starting to falter in their height and physical strength due to various unhygienic behaviours. One glance at any battalion of our standing army, which consists of recruits from the entire country, is enough to show the consequences of such degeneration on the intellectual and material future of our people. On this occasion, it is not necessary to go into details about this. To both you and me it is completely clear that the government needs to devote serious attention to this decrease of strength in our people, and that was why I took the liberty to propose to you to jointly do as much as we can, from our specific ministerial positions, on improving the health and physical strength of our people." - from the letter of Milutin Garašanin to Stojan Novakivić, 13 October 1881.

This elaborate letter, sent to the Minister of Education and Church Affairs Novaković, proposes solutions for numerous important issues regarding the health care, education system, sport and child upbringing: "the es- 

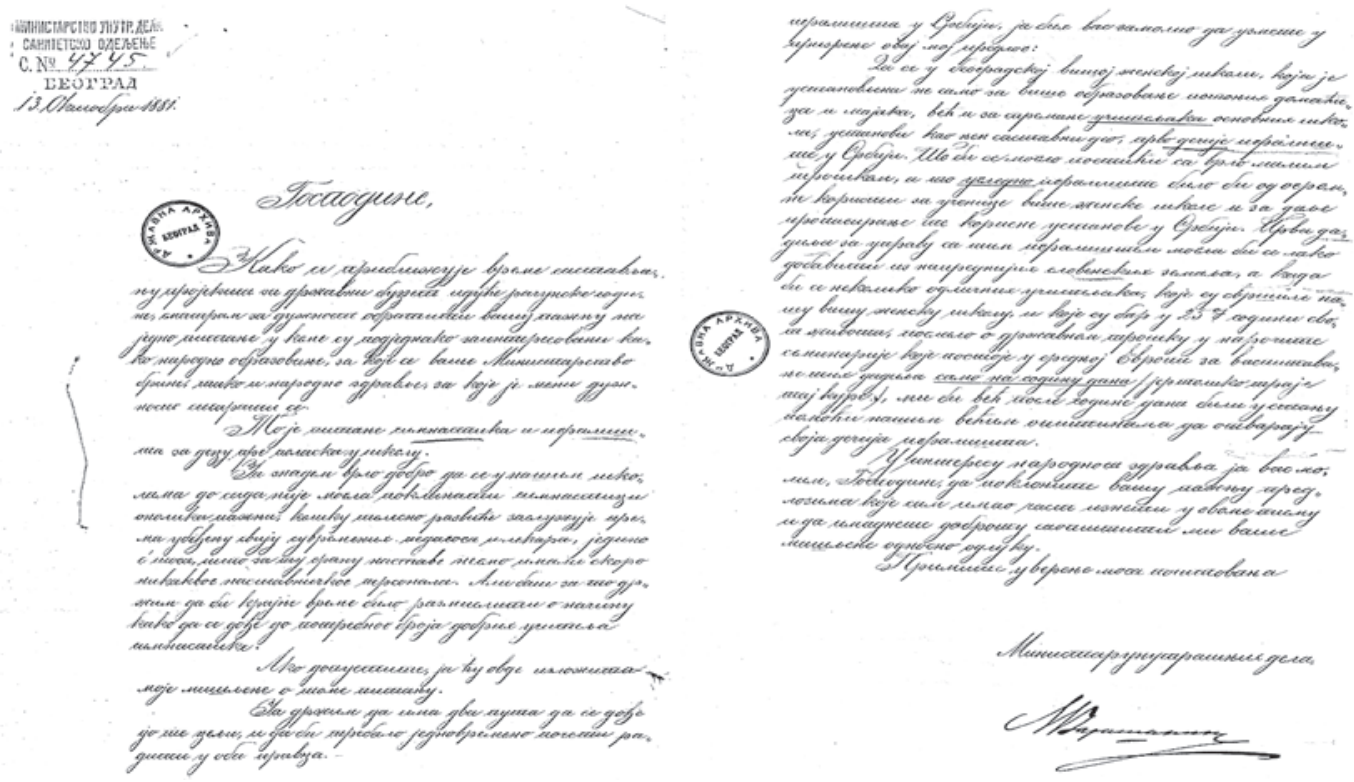

Photo 8. Milutin Garašanin's letter to Stojan Novaković, the first and the last page, 1881

tablishment of a large gymnastic society in Belgrade, with as many physicians and teachers as members, numbering at least several hundred; the construction of a building where gymnastics could be practised in both summer and winter; the training of gymnastics teachers for the work in middle, and later in elementary schools, who should not be amateurs or dilettantes, but thoroughly and specially educated experts in this line of work; the training of gymnasts who would gradually establish gymnastic societies in their own small towns; these local societies would maintain contact with the central gymnastic society in Belgrade, thus making one huge network of institutions, which would, by avoiding pointless entertainment, and working in accordance with a common hygiene plan, drastically improve the level of physical health in Serbia in several years; setting aside certain funds in the Ministry budget for the purpose of sending a few intelligent, healthy and successful gymnastics students to Stockholm for further training as gymnastics teachers; a legal equalisation of gymnastics teachers with the other ones; opening of playgrounds for pre-schoolers - "Fröbel's Playground", also known as "Kindergarten", first in the Women's Higher School; sending several female teachers to Central Europe to a one-year seminar at the government expense..." (Archives of Serbia, Ministry of Education s-p, 1881).

Although Minister Novaković had differing opinions on a number of issues, he supported the proposal to establish a gymnastic society, because this idea had already taken root in the public. Dr Vladan Djordjević was at that time admired as a politician and a writer and for that reason, he easily convinced gymnastics teachers Stevan Todorović, Ferdo Mihoković and Ljubomir Ilić to teach gymnastics for free. Because of Mihokovićs illness, Dr Dragiša Stanojević joined the society (Trujić, 1976).

So as to avoid the waining of enthusiasm, Djordjević immediately gathered respected residents of Belgrade in "Srpska kruna" kafana (20 October 1881) - a total of 33 signatories, excited with this noble idea useful for the people, invited to form the founding board. Among them, there were Dr Laza Kostić, Milan Dj. Milićević, Dr Laza K. Lazarević, Milorad Šapčanin, Mita Cenić, as well as Radivoj Milojković, Milutin Garašanin and Nikola Pašić, the leaders of Liberal, Progressive and Radical parties. The decision to establish The Belgrade Society for Gymnastics and Martial Arts was made on 20 December, while the first session of its assembly and managing body were held on 3 January 1882 in "Srpska kruna". A former minister, general Tihomir Nikolić, was elected as the president, Stevan Todorović as vice-president, while Dr Vladan Djordjević and Dr Laza Kostić, along with the other gentlemen, became the "managing members" (Srpske novine, 1882). With this, The First Serbian Company for Gymnastics and Martial Arts, which had arisen from Stevan Todorovićs Painting School (1857), was restored. 
The course for older children and women and the course for 6-10-year-old children were introduced during the very first days of the Society's existence. The course for women was taught by Women's Higher School gymnastics teacher Stanislava Višekova (from February 1882), while men practised fencing at Delijska fountain from July 1882 (Trujić, 1976; Petrović, 1983). After two and a half months, Dr Vladan Djordjević replaced general Nikolić as the president of the Society, and over the next ten years he would serve as president on two occasions (1882-1884 and 1889-1891), and once as vice-president (1886-1888) (Ilić and Mijatović, 2006).

Djordjević and Stevan Todorović signed the Statute on the Work of the Society, where they listed the Society's specific goals and the program of activities in five points (Ilić and Mijatović, 2006):

- the physical strength and health of the greatly respected members are to be improved through "systematic physical exercises, going out on picnics, marching, fencing and fighting with pencils";

- "care is to be taken to establish suitable companies throughout the country, which would work on spreading the national consciousness, besides improving physical strength of the people";

- "particular gymnastics classes and practical exercises aimed at members of both sex are to be organised";

- "particular care is to be taken when organising official exercising events, about national games aimed at physical strengthening", and

- "gymnastics teachers are to be trained at the Society's expense".

The Society became ambitious and its program institutionalised. Gymnastics was promoted and the establishment of gymnastic societies in other towns in the Kingdom of Serbia was assisted: in Zaječar and Šabac in 1882, in Smederevo in 1885, in Kragujevac... (Vukašinović et al., 2015). Djordjević joined the difficult endeavour of introducing physical exercising with his duties in the civilian medical service. While calling for the gymnastic societies to be established in other towns he wrote and spoke that the "Serbian youth is becoming more and more malformed, and this can be seen on the recruits from the entire country". Though he held a privileged position, he was devoted to and persistent in his mission. He was known for not having left anyone without an answer. Such devotion and politeness encouraged sports enthusiasts (ibid.).

Djordjević made it possible for the information about gymnastic activities and the experiences of gymnasts to be published in the weekly "People's Health". Belgrade residents sent "Instructions", "Statutes", "Gymnasium Rules" and their membership card forms as evidence of attendance, which was considered a basis for the establishment of the organisation. In this paper, Djordjević published an article titled "Gymnastics for Small Children" (1881). Besides giving their moral and expert support in joint public exercising events, the Belgrade residents also assisted various societies with the purchasing of equipment (Vukašinović, 2016). Djordjević also wrote an article titled "Children's Playground" ("Fröbel's Gardens"). He gave a lecture on this topic in the National Theatre at the second yearly banquet of the Society (1883), and on that occasion, the comedy "A Woman's Tears and Gymnastics", which he wrote a year earlier, was performed (Subotić, 1910).

Over time two gymnastic movements - "Soko" and "Dušan the Mighty" - emerged from the gymnastic "tournament" system, and Djordjević, who considered their rivalry detrimental to the development of gymnastics in Serbia, continued his support of this sport, and later of the Sokol Movement, even though he was no longer directly involved in gymnastic societies. The significance of Djordjevićs contribution to the development of gymnastics and the Sokol Movement is immense. With the establishment of the First Belgrade Society for Gymnastics and Martial Arts organised physical exercising was continued after two decades of inactivity in this field, along with the founding of similar civilian gymnastic organisations throughout Serbia, instructing of members on the importance of exercising and training of teachers. That was how the conditions were made for the gymnastic organisation to one day readily adopt the Czech Sokol exercising system, which would, with its further developments, serve as a good basis for the advent and development of modern sports in Serbia (Vukašinović, 2016a).

Time soon showed how visionary Djordjević was in predicting the important role civilian gymnastic societies would play in Serbia in the development and popularisation of physical culture - physical exercising, PE in schools and sport in general. For his contributions to the development of physical exercising in the Kingdom of Serbia, the Sokol Movement representatives in the Kingdom of Yugoslavia granted him the status of the honorary founding member (1938) and proclaimed him "the father of gymnastic societies and a pioneer of the Sokol Movement" (Dragić, 1938). 


\section{VLADAN DJORDJEVIĆ, A VISIONARY OF SERBIAN, EASTERN AND WESTERN PROVENIENCE}

Medical colonel Dr Vladan Djordjević, the first Serbian surgeon, academic, diplomat, prime minister, minister, politician, scientist, writer, historian, chief of civilian and military medical services, founder of the Serbian Medical Association, the Red Cross of Serbia, Niš Military Hospital, founder of numerous educational and sport institutions, gave much to Serbia towards the end of the $19^{\text {th }}$ and the beginning of the $20^{\text {th }}$ century with his fruitful mission. He was a visionary and an author of inexhaustible energy and spirit, an erudite ahead of his time. He had been elected a regular, correspondent and an honorary member of 17 medical, historical, literary and diplomatic societies in Serbia, Germany, France, Belgium, Switzerland, Spain, Russia and Greece. When he was 25 he was elected to the position of a regular member of the Board for Natural Sciences and Mathematics and the Board for Philosophy in the Serbian Learned Society. In 1888 he was elected a correspondent member for philosophy in the Serbian Royal Academy, and for the regular one in 1892. His list of decorations includes 29 medals, orders and war memorials awarded to him by European emperors, kings and science academies.

Alone, old and ill, Vladan Djordjević passed away on 31 August 1930 in Baden. The people gave this great man, who faithfully followed his passion for work and truth throughout his life, all the while being respectful of himself and his nation, a modest funeral, without publicity or pomp. The residents of Belgrade soon forgot him, as is usually the case among the Serbian people. He wasn't honoured with even a street or an alley being named after him.

\section{REFERENCE}

1. Arhiv Srbije, MPS-p, 1881. 18, 110: Pisma ministru Garašaninu povodom inicijative osnivanja Gimnastičkog društva. [Letters to Minister Garašanin on the occasion of Gymnastics society founding initiative. In Serbian].

2. Arhiv Srbije, Vladan Djordjević, lični fond, [Vladan Djordjević, personal fund. In Serbian] 1969. 18441930: 27, 63, 87, 89, 94, 106, 178, 181-185.

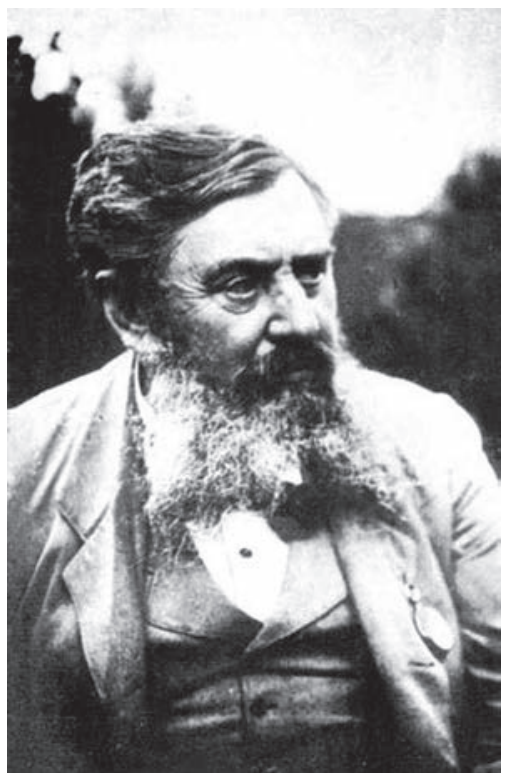

Photo 9. Vladan Djordjević at an advanced age

Dr Vojislav Subotić wrote the following about Vladan Djordjević: "I always admired his great mind, superb intelligence, tireless effort, diligence and persistence in work". [...] "He was great and mighty, he was attacked and he attacked others, he was respected and hated, sharp with his pen, indomitable in speech - and the most important thing of all - an honest man his entire life" (15 February 1910). Vladan Djordjević wrote this on the last pages of his book "A Minister in Jail": "Imprisonment was the first time in my life that I had nothing to do" [...] "If I were to live again I would change absolutely nothing; I would live that new life exactly as this one". [...] "Life without all of that would be nothing more than despicable" (1909).

3. Biografije novih akademika, Dr Vladan Djordjević. [Biographies of new academics, Dr Vladan Djordjević. In Serbian]. Godišnjak Srpske kraljevske akademije 8, 1895: 117-120, 121-124, 132-133.

4. Biografije akademika, Dr Vladan Djordjević. [Biographies of academics, Dr Vladan Djordjević. In Serbian]. Godišnjak Srpske kraljevske akademije 21, 1908: 423-425. 
5. Čolović R. (2007). Doprinos dr Vladana Djordjevića stručnim sastancima srpskog lekarskog društva. [Contribution of Dr Vladan Djordjević to professional Serbian medical societies meetings. In Serbian] Srpski arhiv za celokupno lekarstvo 135(11-12): 689-95.

6. Ćorović, V. (2010). Istorija Srba. [History of Serbs. In Serbian] Beograd: Makibook.

7. Dragić, M. (1938). Dr. Vladan Djordjević, pionir Sokolstva u Srbiji. [Dr Vladan Djordjević, pioneer of the Soko movement in Serbia. In Serbian]. Sokolski glasnik, Savez Sokola Kraljevine Jugoslavije, 16. decembar; IX, 46:1. Beograd.

8. Djordjević, V. (1909). Golgota, roman iz balkanskog života. [Golgotha, the novel from the Balkans life. In Serbian]. Beograd: izd. I. Daničića, „Štampa“.

9. Djordjević, V. (1905). Kraj jedne dinastije, prilozi $z a$ istoriju Srbije, 1-4. [The end of one dynasty, addendums to the history of Serbia, 1-4. In Serbian] Beograd: štamparija D. Dimitrijević.

10. Djordjević, V. (1909). Ministar u Apsu. [Minister in jail. In Serbian]. Beograd: Štamparija St. M. Ivkovića i komp.

11. Djordjević, V. (1927). Усйомене, кулииурне скище из gруїе йоловине 19. века, 1. [Memories, cultural sketches from the second half of 19 century, 1. In Serbian]. Novi Sad: knjižara "Slavija“.

12. Ilić, S, and Mijatović, S. (2006). Истиорија фuзичке кулитре Кнежевине и Кратьевине СрSuje, geo 3. [History of Physical Culture of the Principality and Kingdom of Serbia, part 3. In Serbian]. Belgrade: Faculty of Physical Culture of Belgrade University.

13. Jovanović, В. (1957). Поводом стогодишњице организованог физичког васпитања у Србији. [On the occasion of hundred years of organised physical education in Serbia. In Serbian]. Physical culture 7-8. 326-332.

14. Jovanović, S. (1929). Vlada Aleksandra Obrenovića, 1. [Government of Aleksandar Obrenović, 1. In Serbian]. Beograd: knjižarnica G. Kona.

15. Jovanović, S. (1935). Vlada Aleksandra Obrenovića, 2. [Government of Aleksandar Obrenović, 2. In Serbian]. Beograd: knjižarnica G. Kona.

16. Jovanović, S. (1926). Vlada Milana Obrenovića, 1. [Government of Milan Obrenović, 1. In Serbian]. Beograd: knjižarnica G. Kona.

17. Jovanović, S. (1925). Djordjević Vladan dr. [Djordjević Vladan Dr. In Serbian]. U: Stanojević S, urednik. Narodna enciklopedija, 1. Zagreb: Bibliografski zavod; 693.

18. Lukić, M. http://miljalukic.blogspot.com /2010/09/vladan-djordjevic-beograd-21.html (Tu i tamo) - Vladan Djordjević - Čovek za sva vremena. Pristupljeno 5.082015.

19. Petrović, V. J. (1983). Физичка култура до 1941. год. [Physical culture until 1941. In Serbian]. In M. Maletić (ed.), Sociajalistička republika Srbija, II tom. Beograd: Književne novine.

20. Rajić, S. (2010). „Istorijska čitanka - o dr Vladanu Djordjeviću “. [Historical reader - about Dr Vladan Djordjević. In Serbian]. Feljton, Večernje novosti.

21. Savić, Z. (2014). Istorijski pristup proučavanja života i dela sanitetskog rezervnog majora dr Djordja Mihajlovića. [Historical approach to study of life and work of military medical service reserve major Dr Djordje Mihajliović. In Serbian]. Acta medica Medianae; 53(2): 58.

22. Slapšak, S. (1988). Vladan Djordjević: jedna nepodnošljiva vitalnost. [Vladan Djordjević: one flagrant vitality. In Serbian]. Beograd: Nolit.

23. Srpske novine. [Serbian papers. In Serbian]. 5.01.1882. i 3.04.1882.

24. Subotić, V. (1910). Doktor Vladan Djordjević, pedesetogodišnjica književnog rada. [Dr Vladan Djordjević, the fiftieth anniversary of literary work. In Serbian]. Beograd: Nova štamparija S. Radenković.

25. Trujić, N. (1976). Физичка кулитура у школама Cрбије y 19. векy. [Physical Culture in schools in Serbia in the 19th century. In Serbian]. Beograd: Komisija za istoriju, arhiv i muzej fizičke kulture Srbije.

26. Vukašinović, V. (2016). Гимнастиика и соколсииво у Србији gо 1941. іолине, великани срйске іимнасиике и соколсивва. [Gymnastics and Sokol in Serbia until 1941, great names of Serbian gymnastics and Sokol. In Serbian]. Beograd: University of Belgrade, Fakultet sporta i fizičkog vaspitanja.

27. Vukašinović, V. (2016a). Gradjanska gimnastička društva i sport u Kraljevini Srbiji. [Civil gymnastics associations and sports in the Kingdom of Serbia. In Serbian]. Fizička kultura (70)1, 23-33.

28. Vukašinović, V. (2017). Stevan Todorović, život i delo vežbača, umetnika, prosvetitelja i začetnika organizovanog sporta u Srbiji. [Stevan Todorović, life and work of a performer, artist, educator 
and founder of organized sport in Serbia. In Serbian]. Fizička kultura (71)2, 118-126.

29. Vukašinović, V., Mijatović, S., Veličković, S. i Šiljak, V. (2015). Prilog proučavanju osnivanja društava za gimnastiku i borenje u Kraljevini Srbiji. [Addendum to the study of gymnastics and combat association foundation in the kingdom of Serbia. In Serbian]. Fizička kultura, 69(1). 44-50.

\title{
VLADAN DJORDJEVIC, VIDA Y OBRA DEL ATLETA, CIENTÍFICO, POLÍTICO, ESCRITOR, FUNDADOR DE LA GIMNASIA SERBIA Y DEL MOVIMIENTO SOKOL
}

\begin{abstract}
Resumen
Vladan Djordjevic pertenecía a una generación de los estudiantes del Liceo de Belgrado, que posteriormente llegaron a ser influyentes trabajadores científicos, culturales, sociales y políticos. Una actividad sin descanso en la vida pública social de Belgrado y del Reino de Serbia, el desempeño destacado de los oficios estatales y las funciones diplomáticas, una imponente obra creativa en medicina, historia y literatura, ponen a Vladan Djordjevic en el mismo tope de las personalidades importantes de la historia de Serbia. Además de los méritos en trazar la vida social, cultural, científica y política de Serbia ha dado una enorme contribución al desarrollo de la cultura física en el Reino de Serbia a finales del siglo 19 y al principio del siglo 20. Como estudiante del Liceo de Belgrado, practicando gimnasia y artes marciales, Djordjevic se hizo amante de ejercicios físicos y se dio cuenta de su importancia para la salud y fortalecimiento del espíritu y se les adjuntó. Djordjevic no podía olvidar este inicio de gimnasia organizada y veinte cuatro años después, como un médico respetable y jefe del Departamento de Sanidad en el Ministerio de Asuntos Interiores, llega a ser el autor de la idea de fundar „una gran sociedad gimnástica en Belgrado con las sucursales por toda Serbia“. El desarrollo de la gimnasia en Serbia condicionó dentro de poco la aceptación del movimiento Sokol y la aparición del deporte moderno. El objetivo del trabajo es estudiar y elaborar, aplicando el metido histórico, los documentos auténticos de 1895, 1908, 1910, 1925-1927, 1938, etc., en general desconocidos y no disponibles al público en general y profesional que alumbran las contribuciones multifacéticas del doctor Vladan Djordjevic y sobre todo en la cultura física.
\end{abstract}

Palabras claves: VLADAN DJORDJEVIC / CULTURA FÍSICA / MEDICINA / LITERATURA / HISTORIA / POLÍTICA / SERBIA

Reacived: 01. 04. 2018. Accepted: 12.05 .2018 


\title{
ВЛАДАН ЂОРЂЕВИЋ, ЖИВОТ И ДЕЛО ВЕЖБАЧА, НАУЧНИКА, ПОЛИТИЧАРА, КЫИЖЕВНИКА, УТЕМЕЉИВАЧА СРПСКЕ ГИМНАСТИКЕ И СОКОЛСТВА
}

\author{
Владан Вукашиновић \\ Универзитет у Београду, Факултет спорта и физичког васпитања, Србија
}

\begin{abstract}
Сажетак
Владан Ђорђевић припадао је генерацији београдских лицејаца, касније утицајних научних, културних, друштвених и политичких посленика. Неуморно деловање у јавном друштвеном животу Београда и Краљевине Србије, запажено обављање државних послова и дипломатских функција, импозантан стваралачки опус у медицини, историји и књижевности, сврставају Владана Ђорђевића у сам врх знаменитих личности из историје Србије. Поред заслуга у трасирању друштвено-културног, научног и политичког живота Србије, пружио је и огроман допринос развоју физичке културе у Краљевини Србији крајем 19. и почетком 20. века. Као београдски лицејац, вежбајући гимнастику и вештине борења, Ђорђевић је заволео и увидео значај телесног вежбања за здравље и снажење духа и постао му привржен. Овај почетак организованог вежбања гимнастике Ђорђевић није могао да заборави, и двадесет четири године касније, као угледни лекар и начелник Санитетског одељења Министарства унутрашњег дела, постаје зачетник идеје да се оснује „велико гимнастичко друштво у Београду са огранцима по Србији“. Развој гимнастике у Србији условио је убрзо прихватање соколства и појаву модерног спорта. Циљ рада је да се применом историјског метода проуче и обраде аутентична документа из 1895, 1908, 1910, 1925-1927, 1938. и др, углавном непозната и недоступна широј и стручној јавности, која осветљавају свестране доприносе др Владана Ђорђевића, посебно у физичкој култури.
\end{abstract}

КљУчне речи: ВЛАДАН ЂОРЂЕВИЋ / ФИЗИЧКА КУЛТУРА / МЕДИЦИНА / КЊИЖЕВНОСТ / ИСТОРИЈА / ПОЛИТИКА / СРБИЈА

\section{ЖИВОТОПИС ВЛАДАНА ЂОРБЕВИТА - ВЕЧНОСТ ЗНАҢА, ДЕЛА, ВРЛИНА}

Доктор Владан Ђорђевић, маркантна фигура из историје Србије, својим интелектуалним, организационим и радним потенцијалима оставио је снажан печат у научном, културном, друштвеном и политичком животу Србије крајем 19. и почетком 20. века. Овај интелектуалац, српски лекар, познат и ван граница Србије, оставио је за собом дубоке трагове, вредна дела, идеје и схватања којима је мењао Србију на боље и креирао јавни живот у њеној престоници у Београду. Свестран и авангардан, импулсиван и истрајан, оснивао је, осавремењавао, доприносио медицини, санитету, војсци, политици, дипломатији, културном и друштвеном животу, књижевној и историјској публицистици, школству, спорту.., свему ономе где би се нашао и чега би се прихватио да ради. У сваком послу био је неуморан, одлучан, иновативан, савремен, значајан за напредак друштва и државе Краљевине Србије.

Бројни подаци осликавају Ђорђевићева различита интересовања и организационе и радне потенцијале у бројним пословима којима се бавио. Нешто мање је истражен његов допринос развоју физичке културе, односно, телесног вежбања, грађанске и школске гимнастике, које ће условити појаву савременог спорта и соколства у Краљевини Србији крајем 19. и почетком 20. века. Циљ рада је да се напред изнесена констатација о изузетности др Ђорђевића потврди чињеницама до којих се дошло историјским методом. Поред тога, 
циљ рада је један непретенциозан прилог проучавању дела познатих и историјски афирмисаних српских интелектуалаца.

\section{СВЕСТРАНОСТ И АМБИЦИОЗНОСТ МЛАДОГ ИПОКРАТА}

Владан Ђорђевић рођен је у Београду 21. новембра 1844. године, у Господарској улици (данас Васина улица) у породици цинцарског порекла. Отац Ђорђе Ђорђевић, санитетски помоћник, касније поручник у српској војсци, пореклом из Епира на граници северне Грчке, и мајка Мариja, рођена Леко, из познате београдске породице цинцарског порекла, у жељи да им друго дете постане лекар дали су му на крштењу име Ипократ, по Хипократу. Породица Ђорђевић није имала среће са породом, за кратко време умрло им је троје деце. Ипократ је у седмој години живота остао и ठез мајке која је преминула непосредно након порођаја. Отац је исписао Ипократа из грчке школе и преселио породицу у Сарајево да би се бавио апотекарством. Српску школу у Сарајеву Ипократ је завршио са одличним успехом, и због његовог даљег школовања породица се вратила у Београд. Показавши завидно знање одмах је уписан у други разред Прве мушке гимназије (Ђорђевић, 1927).

Приликом уписивања Београдског лицеја (1862, прве више школе у Србији), на наговор декана, познатог филолога Ђуре Даничића, Ипократ је променио име у „српскије“ - Владан, које је настало као превод другог дела његовог крштеног

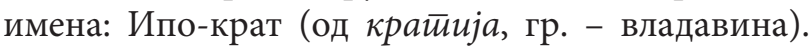
После прве године Лицеја, иако је већ био виђен као студент лингвистике и будући књижевник, дилему даљег школовања разрешили су лицејски професори. Процењујући његове могућности на природном смеру одредили су га за студије медицине, а највећи утицај у томе имао је још један знаменити професор - Јосиф Панчић (Суботић, 1910).

Током школовања на Лицеју Ђорђевић је био члан Дружине за іимнастику и бореюе при Сликарској школи коју је основао Стеван Тодоровић (1857). У свом приватном „заведенију“ Стева је предавао цртање, сликање, певање и глуму, али како је био велики заљубљеник у гимнастику и мачевање, подучавао је лицејце и овим вештинама
(Вукашиновић, 2017). Упркос конзервативним схватањима, Дружина је привлачила ђачку омладину, посебно и због подршке кнеза Михајла Обреновића. Било је то време огромног патриотског полета усмереног ка културним променама и друштвеном напретку Кнежевине Србије, и коначном ослобођењу од Турака.

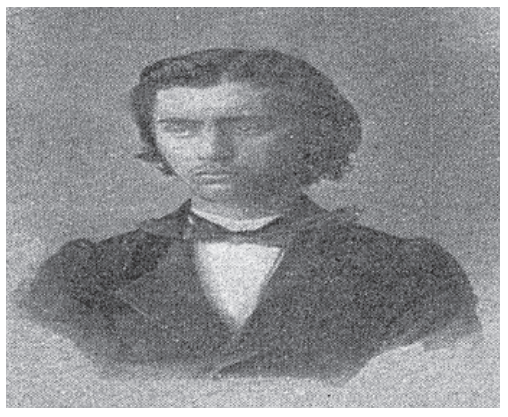

Слика 1. Гимназијалац Владан Ђорђевић

Ипократ Владан Ђорђевић вежба у Сликарској школи у друштву лицејаца који ће у будућности бити познати политичари или научници: Милош С. Милојевић, Милан Кујунџић, Чеда Мијатовић Љубомир Каљевић, Стева Поповић - Црни, Андра Николић (Петровић, В. J, 1983). „Шћева“, како су свог учитеља од миља звали млади поклоници телесног вежбања, настојао је да своје ученике поред вежбања свестрано просвећује и васпитава у патриотском духу (исто). Ђорђевић није био само обдарен за вештине гимнастике и мачевања, рано је почео да се интересује за књижевност и пише драмске радове са великим надахнућем. Проучавао је историју, учио језике и преводио, у петом разреду већ је читао романе и часописе на немачком, учио је да слика и свира клавир, играо је у позориштима (Ђорђевић, 1927). Може се рећи да се истицао бројним интересовањима и жељом за усавршавањем.

\section{ДР ВЛАДАН ЋОРЂЕВИК, ПРЕДАНОСТ ПРОФЕСИЈАМА, У СЛУЖБИ НАРОДА}

У јесен 1863. Владан Ђорђевић је послат као државни питомац на престижни бечки медицински факултет. Предавали су му чувени професори медицине Хиртл, Брике, Рокитански, Шкода, Хебра, Зигмунд и славни професор хирургије Тодор Билрот, који ће га прогласити својим нај- 
даровитијим студентом. То је Ђорђевић потврдио бриљантном одбраном тезе крајем 1868, а већ у јануару 1969. промовисан је за доктора медицине, а само пет месеци касније, и за доктора хирургије, потом и за магистра опстетриције (породиљства) (Годишњак Српске краљевске академије - у даљем тексту СКА 8, 1895). Док је студирао и током двогодишње специјализације у Бечу, под великим утицајем професора Билрота, стекао је завидну вештину оперисања и прихватио „пруску“ тачност, дисциплинованост и организованост у послу. Иако је започео праксу на хируршко-гинеколошкој клиници у Прагу, амбициозни Ђорђевић се вратио у Беч због специјализације хирургије (1869-1871). Рано је скренуо пажњу и првим научним радовима које је писао на немачком, а затим преводио за „Српско учено друштво“. На бечкој клиници стекао је диплому специјалисте хирурга-оператора.

Да би се даље усавршавао „у ратној хируршкој техници“, тражио је допуштење српске владе да учествује у раду санитета током Француско-пруског рата. У великој ратној болници у Франкфурту Ђорђевић се истакао као лекар ординатор и шеф једног одељења, па му је за заслуге додељен чин санитетског поручника у резерви (Суботић, 1910). Ђорђевићева амбициозност, стручна радозналост и резултати нису могли да прођу незапажено. Иако млад, убрзо је биран за редовног члана „Српског ученог друштва“ 1869, „Лекарске задруге“ 1870. и Антрополошког друштва у Бечу 1871. године (Годишњак СКА 8, 1895).

После осам година Ђорђевић се вратио у Србију у јулу 1871. као први школовани српски хирург. У Београду је отворио лекарску ординацију и радио краће време као приватни лекар и оператор. Брзо се прочуло да брине за здравље свог народа и да сиротињу лечи бесплатно и помаже новцем. На јавним скуповима, као и на својим предавањима, предлагао је да се оснују сиротињски дом, болница за сиротињску децу, павиљон за сироте породиље, школе за глуво-нему и слепу децу. Поднео је и молбу Министарству унутрашњег дела да му се дозволи да бесплатно лечи сиротињу и тако одужи држави за добијену стипендију. Уместо одговора, који је чекао пет месеци, указом кнеза Милана постављен је за војног лекара друге класе и шефа хируршког одељења Београдске војне болнице (1871). Поред ове функције, предавао је на првим курсевима болничарске службе и био први предавач војне хигијене у официрској школи, касније у Војној академији (Суботић, 1910). Следеће, 1872. године основао је „Српско лекарско друштво“.

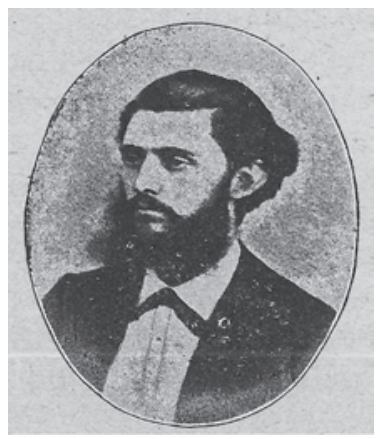

Слика 2. Др Владан Ђорђевић, оснивач Српског лекарског друштва, 1872.

Успешна лекарска каријера, после две године, довешће га до животне прекретнице, 1873. постаће дворски лични лекар осамнаестогодишњег кнеза Милана Обреновића (Јовановић, 1926). Ово ће бити пресудно за даљи развој Ђорђевићеве каријере, његова политичка опредељења и судбину његове породице. У кнезу је видео владара са јасном визијом савремене и напредне Србије, што је Милан Обреновић временом и испољио - способност и мудрост у вођењу спољње и унутрашње политике, заслуге за независност и међународно признавање и територијално увећање Србије и модернизовање државних установа. У првим годинама службовања имао је велики утицај на младог кнеза, па су се његове бројне иницијативе за кратко време реализовале. Уз кнежеву подршку и материјалну потпору државе, покренуо је оснивање и развој важних институција, као што су цивилни и војни санитет, Српско лекарско друштво и Црвени крст. Током седамнаест година службовања, под круном Обреновића (у више наврата), као лекар и потом државни службеник, делио је успоне и падове државе и доживео да му династија неколико пута окрене леђа, или га искористи када им је био потребан.

У првих шест година проведених на двору било је честих непријатности које је Ђорђевић имао због непредвидивости и незгодне нарави кнеза, али и нетрпељивости кнегиње Наталије према њему због искрености у комуницирању. Дворска служठа, интриге и афере постале су му велики терет. Одласком са двора, следећих десетак година руководио је војним санитетом у оба 
српско-турска рата (1876-1878), и у српско-бугарском рату (1885-1886), као и цивилним санитетом када се није ратовало. За успешно организовање санитета, већ после завршетка првог рата, требало је да му се додели чин пуковника, али кнегиња Наталија поцепала је указ кнеза Милана о унапређењу Ђорђевића. Владан је поднео оставку, али је кнез није уважио и одликовао га Таковским орденом, који је имао само руски генерал Черњајев. У српско-бугарском рату из резерве је враћен у активну војну службу, тада му је додељен чин санитетског пуковника, до овог унапређења у српској војсци лекар није могао имати виши чин од мајорског (Суботић, 1910).

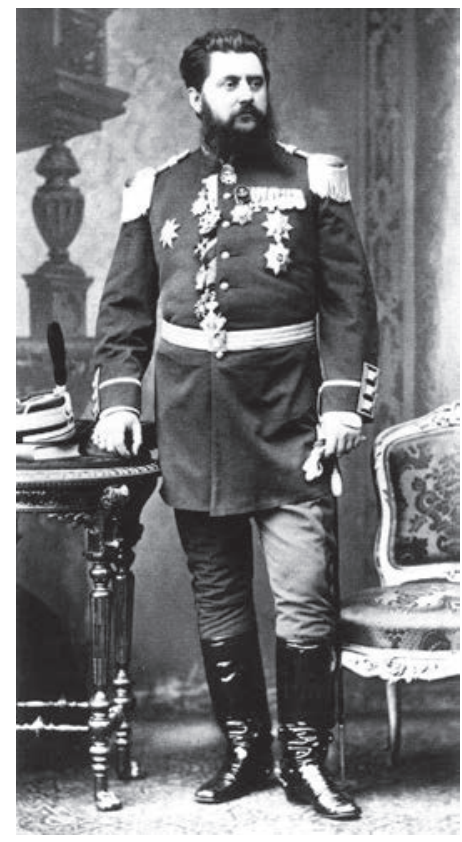

Слика 3. Начелник Санитета др Владан Ђорђевић

\section{ВЛАДАН ЋОРЋЕВИЋ, НЕИСЦРПНА СНАГА И ДОСЛЕДНОСТ НАЧЕЛИМА}

На политичкој сцени Србије др Ђорђевић је почео да се ангажује од 1883 , иако је до тада био политички независан. Заговарао је напредне идеje, култ науке и просвећивање народа, говорио је да је „обреновићевац по оцу“, али да му је била врло блиска идеја „просветитељског духа“, односно, вера у науку и њену просветитељску моћ, јер је „просвећеност народа покретач историјских процеса" (Рајић, 2005). Борио се против продора маса у политику, увиђајући опасности које је до- носио радикализам. Изражен темперамент Ђорђевића и оштре расправе са политичким вођама, па и представницима династије, стварале су му многе непријатности.

Када нису могли да изађу с њим на крај, доктор Ђорђевић постављен је за председника београдске вароши 1884, а прво што је урадио било је да растера бирократе. Током двогодишњег управљања Београдом, веома се успешно носио са новим изазовима уређења вароши. Општински персонал га је поштовао, иако је био строг и није толерисао лењост. Такве особине и појаве називао је „оријенталним јавашом“ ( $\bar{u} y p$. спорост, лењост). Због своје животне крилатице „лаборемус“ (лат. „радимо“), и дуго помињане и цитиране опаске са једног предавања, а штампане у часопису „Отаџбина“ - „Срйско оgушевлене је као йлехана фуруна, која се брзо заірева, али брзо и хлаgи“, сматран је нетипичним Балканцем (Суботић, 1910). Једном приликом најурио је представника беочинске фабрике цемента и обелоданио покушај да га подмити. Доследан својим начелима, због сукоба са министром унутрашњих послова због увођења трошарине, поднео је оставку на функцију председника, али тек пошто су му посланици у скупштини изгласали поверење (Архив Србије, Владан Ђорђевић, лични фонд, 1969). Доктор Ђорђевић знао је да добро усталаса тадашњи инертни београдски миље.

Ђорђевић је био истинољубив, повремено је оштро говорио и писао и о пропустима краља и његовим политичким потезима који су потресали државу и успоравали њен развој. Краљ Милан био је врло осетљив на такве критике. Први већи сукоб догодио се када је Ђорђевић позвао на одговорност и краља и поједине министре за пораз Србије од Бугарске у бици на Сливници новембра 1885. написавши у „Отаџбини“ „голу и горку“ истину о политичком и војничком вођењу рата (1887). Милан Обреновић, увређен, својеручно је написао тужбу да би га послао у затвор, али га суд није осудио. Неколико месеци касније краљ је морао да прихвати да се способном Ђорђевићу повере два ресора у министарству - просвета и црквени послови и привреда (Годишњак СКА 8, $1895)$, али ће и даље остати у краљевој немилости због штампања „праве историје Сливнице“. Тако, исте године, краљ је својеручно избрисао његово име са списка Кујунџићеве листе кандидата за прве академике у Србији (Јовановић, 1935). 
Са великим невољама породица Ђорђевић се суочила када је краљ Милан прерано абдицирао (1889). Одрицање од престола и предавање државе малолетном сину и Намесништву, Владан Ђорђевић је оценио неодговорним и себичним у време нестабилних политичких прилика у земљи. Зато га је неколико дана после абдикације затекло прерано (прво) пензионисање, октобра 1889. (исто). Одласком Милана Обреновића из земље, Ђорђевић се повукао, али на кратко. Обреновићи су га се опет сетили, јер им је био потребан.

Поред бројних дужности које је обављао, др Ђорђевић је као велики поклоник телесног вежбања основао 1881. године Беоіраgско gрушииво за іимнастику и борене, са идејом да се уз помоћ овог „централног гимнастичког друштва поради на оснивању сличних у свакој вароши и варошици ради унапређења здравља и телесне снаге народа“. Ово је био преломни тренутак за развој гимнастике и у другим градовима Србије, као и, убрзо, соколства и појединих спортова (Вукашиновић, 2016, 2016а).

Године 1891. др Ђорђевић је прихватио понуду Намесништва да попуни дипломатско место на двору грчког краља у Атини. Три године успешно је развијао пријатељство између Србије и Грчке, док место није укинуто буџетом, па је други пут пензионисан (јануара 1894). После три месеца постављен је за посланика у Цариграду (априла 1894), важном и непопуларном центру српске спољне политике. У тешким условима које је наметао оријенталан дух препредених дипломата, успешно се борио за виталне српске интересе (Joвановић, 1925, 1929).

Са ове дипломатске функције, на захтев краља Милана који се вратио у Србију, и пошто је млади краљ Александар оборио радикалну владу, Ђорђевић је пристао да образује нову краљевску владу. Као председник министарског савета с портфељом министра иностраних дела имао је тежак задатак да истовремено служи два краља, оба утицајна (екскраљу је дато звање врховног команданта активне војске). Када се под његовим министарством догодио неуспели атентат на краља Милана (Београд, 1899), поднео је оставку, али је убрзо повукао пошто је оптужен од екскраља да се склања кад је најтеже (Ћоровић, 2010; Јовановић, 1935).

Због незадовољства српских официра „неподобном“ веридбом краља Александра и удовице
Драге Машин, Ђорђевић је покушавао на разне начине да одврати младог краља и већ тада је међу њима почео да се распламсава сукоб. После краљевског венчања, поднео је и сам оставку на све функције (1900) и нашао се у још једном у прилици којом је озбиљно изложио и себе и породицу великој несигурности. Са двора су наручивани безочно увредљиви напади у дневној штампи на Владанову личност. Трогодишњи рад његове владе називан је „Владановштина“ и требало је доста времена да би се оценило да су „Владановштина мит и раширена веровања која одговарају врло мало стварности, јер су краљ Милан и краљ Александар режим створили и држали, а не Владан Ђорђевић“(Јовановић, 1935).

У намери да у потпуности унизи Ђорђевића, краљ Александар га је незаконито пензионисао (1900, треће пензионисање), одузета му је чиновничка пензија и пуковнички чин. Разочаран, Владан Ђорђевић, је отишао у Беч, у „добровољно изгнанство“ “како га је сам назвао, где је провео девет месеци пишући за више бечких и једне берлинске новине, док Државни савет Србије није поништио незаконита решења краља (Годишњак CКА 21, 1908). После крвавог Мајског преврата (Београд, 29. маја 1903), када је убијен краљевски пар, провео је још две године у Бечу, а потом се вратио у Србију. Од тада, као министар председник у пензији, бавио се књижевним радом, углавном „на историји“, писао је на немачком и српском. У мемоарима „Крај једне династије“ тако је описао поједине министре, да је завршио у затвору под наводном оптужбом да је одавао државне тајне (1906), међутим, стварни разлог био је јер је написао да „краљица Енглеске није могла да прими посету краља Александра“. Казну је издржао у београдској „Главњачи“ свих „шест месеци тамнице, пошто није хтео да моли за милост коју су му понудили“ (исто). У књизи „Министар у апсу“, о својој намери да после издржане казне оде у Беч, написао је: „одлазим да мало дишем у ма каквој правној држави, у којој патриотизам није кривица." И у време Великог рата, допао је затвора, од 1915. до 1918, када је интерниран надомак Беча. По повратку, живео је у Београду и повремено одлазио у Дубровник.

Владан Ђорђевић је у 86 година дугом, садржајном и нимало лаком животу, преживео шест ратова, промене устава, режима, династија, и био сведок многих крупних историјских догађаја. 
Кривудава животна путања, судбоносно везана за династију Обреновић, доносила му је много тога, углед, част, положај, али и жртве, сукобе, нападе и осуде, три пензионисања, два тамновања. У браку, са три године млађом Немицом Паулином Бритнер, љубав из студентских дана, имао је петнаесторо деце, али, преживело их је само четворо. Најстарији син, капетан прве класе адвокат Милан, погинуо је у првим борбеним редовима приликом ослобађања Дубровника 1918. Други син, Александар, живео је у Паризу, где су и данас Ђорђевићеви потомци. Две кћери имају бројно потомство у породицама Дероко и Властари.

\section{ВЛАДАН ЂОРТЕВИТ, ПРИМЕР ЕРУДИТЕ ЗА ПРОСПЕРИТЕТ ГРАҚАНИНА И ДРУШТВА СРБИЈЕ}

\section{Медицина, војни и цивилни санитет}

Др Владану Ђорђевићу приписују се изузетне заслуге у развоју медицине, војног и цивилног санитета. Комплетно и компетентно је сагледао проблеме и потребе друштва у здравствено-медицинској превенцији и заштити, која се у Србији тек развијала, јер је довољно времена провео у разним службама, од стажирања у престижним клиникама до приватне и државне војне и цивилне лекарске службе.

Ђорђевић је најзаслужнији за окупљање 15 лекара шест народности и оснивање „Српског лекарског друштва” (1872). У Друштву је био први секретар три године, касније потпредседник четири године (1886-1889) и две године председник (1890-1891). Започео је уређивање, превођење и објављивање првих издања стручног часописа „Српски архив за целокупно лекарство” (1874). „Архив” је покренуо у намери да сви српски лекари, ма где живели, прате нова сазнања у медицини. Захваљујући угледу који је имао код краља Милана, Ђорђевић је обезбедио државну помоћ Друштву и бесплатно издавање часописа (Годишњак СКА 8, 1895).

Владан Ђорђевић имао је великог удела и у оснивању “Српског друштва Црвеног крста" (1876). За чланове управе окупио је неколико угледних грађана Кнежевине Србије. Први задатак новооснованог Друштва био је збрињавање избеглица пристиглих у Србију због Херцеговачког устанка. Својим утицајем помогао је да се већ у години оснивања поставе темељи овог друштва и да га призна Међународни комитет Црвеног крста. Рад овог Друштва био је од почетка одлично организован - усмерен на прикупљање новчаних и материјалних средстава, организовање болница, ангажовање лекара, обуку и школовање добровољног болничког особља, набавку санитетског материјала и пружање помоћи војном санитету (Суботић, 1910).

Др Ђорђевић руководио је војним санитетом у свим ратовима које је Србија тада водила. У Првом српско-турском рату (1876) био је начелник Санитетске служठе моравско-тимочке војске, у Другом српско-турском рату (1877-1878), и касније, у Српско-бугарском рату (1885-1886), био је начелник Санитетске службе врховне команде српске војске. У раду санитета у ратним условима показао је изузетне организаторске способности. Основао је и био први управник Војне болнице у Нишу (јануар 1878), познате и као „Моравска војна болница“. Залагањем Ђорђевића утемељена је организација рада нишке војне болнице, тада централне војносанитетске установе југа и истока земље, што ће касније, у балканским и Великом рату бити од великог значаја (Савић, 2014).

Док је предавао болничкој чети у војној београдској болници и војну хигијену у Војној академији написао је уџбенике „Болничка служба“ и „Начела војне хигијене“ (1874). Награђен је за књигу “Упутство за службу војног санитета стајаће и народне војске у мирно и ратно доба” (1876). Издејствовао је да српска војска добије свој санитетски официрски кор. Иницирао је бројне расправе о реформи санитетске струке (1879-1881) (Суботић, 1910).

Као начелник цивилног санитета Србије (од 1879), покренуо је и успешно из основа реорганизовао санитетску службу 1881. Да би спровео широку реформу водио је више година преписку са професорима медицине са универзитета у Паризу, Бечу, Стокхолму и Женеви. О томе су сачувана многобројна писма у којима се изражавају највише оцене европских стручњака о санитетској реформи (Архив Србије, ВЂ).

Ђорђевић је творац законских пројеката и књига у здравству. Чувен је његов изванредно изложен говор у Народној скупштини у коме је као повереник Владе говорио о здрављу у Србији, заразним болестима, сточним заразама, хигијени породиљства, понашању према новорођенчади, 
неуким бабицама, квалитетној исхрани, штетним предрасудама и обичајима по здравље необразованих становника и др. Овај говор је убрзао доношење првог Закона о санитету у Србији (1881, назван “Владанов санитетски закон”). Убрзо је објавио више књига у овој области: “Санитетски зборник закона и уредаба” (службени коментари, упутства и правила за спровођење закона) и др. Заслужан је и за израду ветеринарског законодавства и склапање ветеринарске конвенције између Србије и Аустро-Угарске и оснивање "Народног санитетског фонда”. Основао је и Хигијенски недељни лист “Народно здравље” (1881), у коме је до 1884. био уредник. Као начелник цивилног санитета заступао је Србију на конгресима хигијене у Женеви, Турину и Бечу (Суботић, 1910).

Садржаји детаљно вођених записника са састанака "Српског лекарског друштва", показују да је Владан Ђорђевић доста писао и реферисао о разним хируршким поступцима које је изводио у београдској Варошкој болници, Војној болници, а понекад и у приватним кућама. Већи број својих радова из хирургије је превео (Чоловић, 2007). Иу дубокој старости био је друштвено врло активан, учествовао је у раду “Српског лекарског друштва”, држао предавања и допринео оснивању Катедре за историју медицине на Медицинском факултету Београдског универзитета (1920), али предмет је укинут шест година после његове смрти.

\section{Друштвене функције, политика, дипломатија}

Владан Ђорђевић, иако конзервативни обреновићевац, био је авангардна личност. Велики оптимиста и борац, окренут напретку своје државе, а упознат са дометима савременијих друштава, имао је шта да мења у друштвеном, државном и политичком животу Краљевине Србије. У младости је још као ђак стипендиста, републиканац по убеђењу, као секретар „Уједињене омладине српске“ заговарао „изграђивање васпитања и народне свести“ и „равноправност женскиња са мушкима“ у омладинској заједници. Због свог „слободнијег“ говора на свесловенском конгресу у Москви када се противио „да руски језик буде општи словенски књижевни језик“, министар просвете му је одузео државну стипендију, а коју му је кнез Милан касније вратио (Суботић, 1910). Ђорђевић је мењао политичка уверења, од симпатија према либералима у време студентских дана, временом се приклонио републиканским идејама, да би се на крају, првобитна уверења, због великог утицаја кнеза Милана у кога је у полагао све наде, постепено трансформисала у династичка, због те оданости оправдано су га сматрали ројалистом.

Указом краља Милана, Ђорђевић је постављен за председника београдске општине (1884-1885). Пошто је реорганизовао бирократску администрацију, ударио је темеље у планирању и изградњи комуналне инфраструктуре у Београду: иницирао је изградњу градског водовода и канализације, започео је модернизовање уличне расвете увођењем плинског светла, уређење Савског кеја (Савамала) и планирање трамвајског саобраћаја, калдрмисао је улице, основао пијацу на Цветном тргу, засадио је преко 1000 дрвета, изместио гробље са Ташмајдана на своје велико имање које је поклонио Београду (Ново гробље, некада познато као “Владановац"), увећао је општинске приходе увођењем трошарине, увео је и планирање новчаних средстава за комуналне послове у општинском и државном буџету, покренуо израду опсежног пројекта “Београдски општински послови”, уводио је строге комуналне казне за нечистоћу (14, 1884-1885) (Архив Србије, ВЂ, 1969; Суботић, 1910).

Када су анархија и расуло потресали државу, у напредњачком листу „Видело“, критиковао је радикале за демагогију која „трује народ“ и која ће довести до Тимочке буне (1883) и истицао потребу да се у земљи брани законски поредак. После гушења Тимочке буне напредњаци су му поверили мандат (први) за краљевог посланика. Као посланик остао је бранилац круне и њених права, али и заговорник грађанских и политичких слобода и уређења институција од реда и угледа (Рајић, 2005). Изражен темперамент Ђорђевића, „ठритак језик“ и оштра писана реч у штампи, као и расправама са политичким вођама, па и представницима династије, стварале су му многе непријатности. Водио је оштре јавне полемике са социјалистима, радикалима, напредњацима, либералима и због тога био трн у оку многих, говорило се и писало да „др Владан сече своје противнике немилосрдно и ножем и језиком“. Залагао се за нормалне (ненасилне) политичке токове, идеје државних преврата Светозара Марковића критиковао је сматрајући их погрешним и штетним, писао је да је боље „праве грађанске слободе“ изборити законским средствима и слободом говора 
и штампе. Допринео је усвајању бројних пореских реформи и корисних закона, у циљу државног и друштвеног напретка и интереса земље предлагао је изградњу железничке мреже, формирање праведнијих судова, уређење власти, просвете, војске. Није се мирио са инертним стањем у државним институцијама, с тим у вези, у часопису „Отаџбина“ написао је чланак „Поређење неколиких државних буџета” (1891) захтевајући да се у народној скупштини не приказује лажни државни буџет (Архив Србије, ВТ), 1969; Годишњак СКА 21, 1908).

Године 1888. постављен је за министра просвете и црквених послова и заступника министра народне привреде у влади Краљевине Србије. Потом почиње Ђорђевићева дипломатска каријера, прво је распоређен као посланик Србије у Атини од 1891. и од 1894. у Цариграду (1894-1897). У том периоду у Србији су се мењали кабинети, радикални, неутрални и напредњачки, али су сви били веома задовољни његовим трогодишњим дипломатским ангажовањем. (Јовановић, 1925; Рајић, 2005). “Неуморним обигравањем" и својственом харизмом изградио је добре односе са руском дипломатијом, али и велико пријатељство са султаном Абдул Хамадом, што је помогло у решавању спорних питања са Бугарском и Грчком. Тада је повољно решен лош положај српског становништва и српске православне цркве у Старој Србији (Рашка, Косово, Метохија и Вардарска Македонија) и Македонији (солунски и битољски вилајети), тако што су Патријаршија и Порта одобриле постављање српских владика (рашко-призренског и скопског) и отварање српских школа (Јовановић, 1929). Затим је постављен за председника краљевске владе и министра иностраних послова (18971900). Познато је да је његова „неутрална“ влада радила на економском и војном јачању Србије, стишавању жестоких партијских борби и доношењу великог броја закона.

Интересантан је податак да је Ђорђевић утицао на краља Александра да, по повратку из Цариграда, после обиласка грчког двора посете манастир Хиландар на Светој Гори (1894). Приликом ове посете, прве после средњовековних владара, коначно је решено спорно питање са Бугарима око својине Хиландара, тако што је краљ богатим прилозима у новцу и злату задржао Хиландару статус српског манастира. Од хиландарске братије краљ јер преузео непроцењиво национално благо - Мирослављево јеванђеље, оригиналну Немањину повељу манастиру и неколико вредних рукописа (Лукић, 2010).

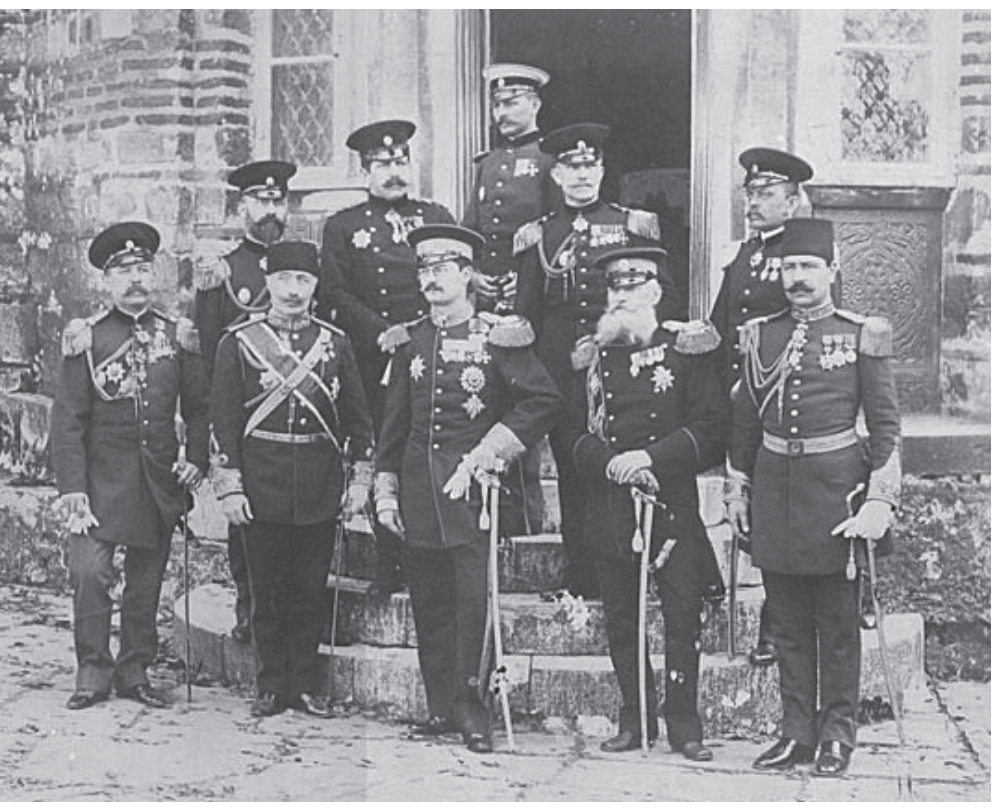

Слика 4. Краљ Александар Обреновић, испред цркве манастира Хиландар, 1894.

\section{Публицистика, књижевност и историја}

Још за живота Ђорђевића су сврставали међу најплодније српске писце. Био је цењен и због импозантног обима књижевног опуса, и енергије са којом је писао романе, приповетке, драме, новеле и песме. У другом разреду гимназије објавио је прву приповетку (1860), од тада је непрестано писао, а у шестом разреду добијао хонораре за драме, трагедије, комедије и преводе. Као студент већ је имао објављених 29 књижевних радова штампаних у часописима „Даница“, „Видовдан“, „Вила“ и др. (Јовановић, 1925; Годишњак СКА 8, 1895).

Био је активан у књижевном друштву „Зора“, и покренуо повезивање са друштвом „Србијанац“, тако је настала „Уједињена омладина српска“, уједињењем чланова из Аустро-Угарске и Србије у Новом Саду, 1866. Када је у овој организацији изабран је за првог секретара и редактора омладинских књига, одмах је формирао преводилачки одсек, за превођење најбољих књижевних светских дела, у циљу просвећивања народа (Суботић, 1910). 
Разноврсна и богата Ђорђевићева библиографија представља драгоцен извор за проучавање седам деценија историје Србије. Критике европске књижевне јавности биле су врло похвалне за већину Ђорђевићевих романа, дела су оцењивана као “документарна, уметничка, објективна, песнички даровита, темељна, са много познавања историје Србије и оријенталних односа, написана на одличном немачком". Своје радове писао је на више језика, поједини тротомни романи премашују и 1500 страница. Преводио је са руског, француског, немачког, новогрчког (Толстојеву „Ану Карењину“, Молијеровог „Тврдицу“, затим, Балзака, Ауербаха, Голдонија и др.) (исто). Допринео је и приближавању српске и грчке културе: написао је велику студију упоређујући два просветитеља - Кораиса и Доситеја („Грчка и српска просвета“, 1896), превео је на грчки приповетке свога кума др Лазе К. Лазаревића, писао је са великим занимањем о новогрчкој култури. Поред око 180 радова у медицини, историји и књижевности, сачуван је и позамашан фонд његових рукописа научних и књижевних дела, беседа, полемика, чланака, предавања, фељтона, мемоара, дипломатских извештаја, пројеката законских прописа, писама и критика публикованих у разним недељним и дневним српским и страним листовима, као и непубликованих („Србија и Руси“...) (Годишњак СКА 8, 1895; Слапшак, 1988).

У попису важнијих Ђорђевићевих дела су: “Историја српског војног санитета", 1-4 (18791886), “Крај једне династије”, 1-3 (1897-1900), “Србија на берлинском конгресу” (1890), “Српско-турски рат”, 1-2 (1907), “Историја српско-бугарског рата", 1-2 (1908, Министарство војно откупило је 200 комплета са оценом да је “права генералштабна историја тога рата"), "Голгота“" (1909, 31 изузетна критика), “Министар у апсу” (1909), “Сербика” (1909, историјска студија са збирком од 800 докумената о историји Србије и Црне Горе од 1804. до 1815. године, чува се у Српској академији наука и уметности), "Albanesen und die Grossmachte" (1913, Албанци и Велике силе, прим. аут.), “Цар Душан”, 1-3 (1919-1920), “Црна Гора и Аустрија” 1814-1894. (1924), „Успомене”, 1-5 (1927) (Суботић, 1910; Ђорђевић, 1909).

Ђорђевић је издавао и уређивао књижевни часопис “Отаџбина” (1875-1892), један од најзначај- нијих књижевних часописа у Србији у 19. веку, у коме су објављивали готово сви познати српски писци осамдесетих и деведесетих година (Слапшак, 1988). Часопис је сам финансирао, сматрајући то питањем части и могућношћу да истинити и образовни садржаји без цензуре доспу до читалаца. На првој страни часописа, у заглављу, да би се у сваком српском читаоцу пробудио понос, стајали су стихови чувене песме Ђуре Јакшића "Отаџбина“, тиме се Ђорђевић нарочито поносио. Песму је Ђура, и сам оштар на језику као и Владан, написао на новини за кафанским столом у „Дарданелима” (на месту данашње Палате Албанија), из душе и ठез преправки, пошто му је добро дошао ручак који је платио Ђорђевић. А на поцепаном комаду новинског папира: ": “И овај камен земље Србије, што претећ небу дере кроз облак...” (Лукић, 2010).

\section{КРОЗ ГИМНАСТИКУ И БОРЕЊЕ ДО ГРАҚАНСКИХ И НАЦИОНАЛНИХ ВРЛИНА ВЕЖБАЊЕМ}

У десетогодишњем периоду (1881-1891) када је Ђорђевић из основа реорганизовао санитетску област, уређивао санитетско и ветеринарско законодавство, док се ангажовао у бурном политичком животу као посланик и предлагао пореске реформе и промене у државним институцијама, те успешно управљао београдском вароши, исписао три вишетомна дела из медицине и историје, и са својом породицом подносио велике ударце од критикованог Милана Обреновића, стизао је и да оснива грађанска гимнастичка друштва у Србији. Октобра 1881. године био је иницијатор оснивања Беоіраяскоі gрушитва за іимнастинку

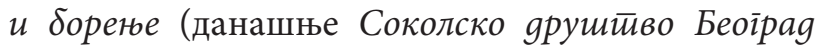
Матиица) које ће брзо имати велику подршку и помоћ грађанства, добротвора и министарстава просвете, унутрашњих послова и војске. Са пријатељима, некадашњим лицејцима и познатим личностима на значајним положајима, захваљујући давнашњој наклоности према гимнастици и својој чудесној животној снази и радној кондицији, успешно је подизао углед Друштва, помагао оснивање других гимнастичких друштава и стручно школовање учитељског гимнастичког кадра (Вукашиновић, 2016). 


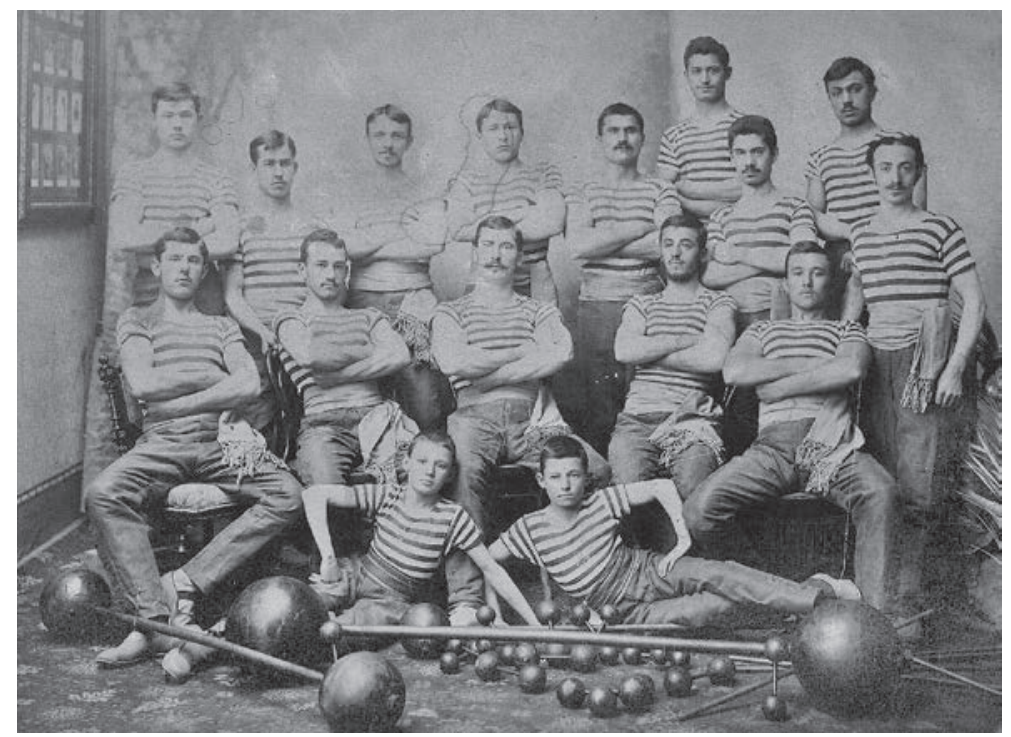

Слика 5. Београдско друштво за гимнастику и борење, 1889.

јер су све више у Србију пристизала позитивна сазнања о соколству и спорту, те подржава иницијативу да се организује једно велико гимнастичко друштво, са огранцима по Краљевини Србији, и упућује писмо министру просвете и црквеног дела Стојану Новаковићу. По садржају писма и стилу писања није тешко претпоставити да је аутор прослеђеног опширног писма, с потписом министра Гарашанина, ревносни и систематични др Владан Ђорђевић, с обзиром на темељност у образлагању поразног стања здравља омладине и народа, као и бројних предлога за институционално, материјално и кадровско решавање питања увођења школске и грађанске гимнастике:

„Ја знадем врло добро да се у нашим школама до сада није могло поклонити

\section{Телесно вежбање, школско физичко васпитање и спорт}

Као лицејац млади Ипократ заволео је гимнастику и увидео колико је важна за здравље, телесне и умне способности. Овај почетак организованог „гимнастисања“ и одушевљење лицејаца Стевиним педагошким умећем да их учи уметничким и спортским вештинама у Сликарској школи, Владан није заборавио.

Четврт века касније, као угледни хирург, војни лекар и начелник цивилног и војног санитета др Владан Ђорђевић покреће идеју о оснивању друштава за гимнастику, апелом у писму министру унутрашњих дела (послова) Милутину Гарашанину. Гарашанина није требало много убеђивати

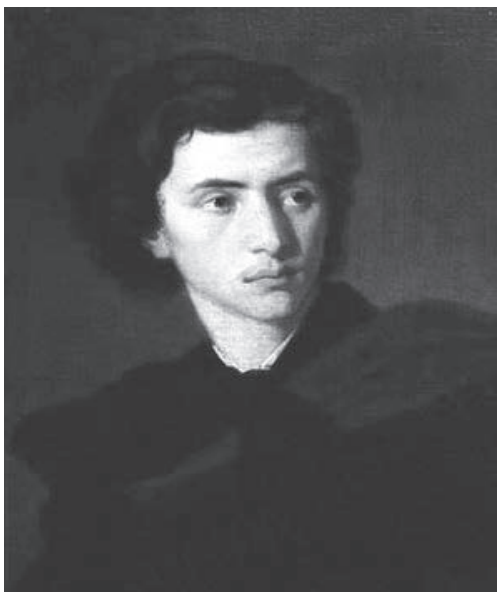

Слика 6. Ипократ Владан Ђорђевић, слика Стеве Тодоровића, уље на платну

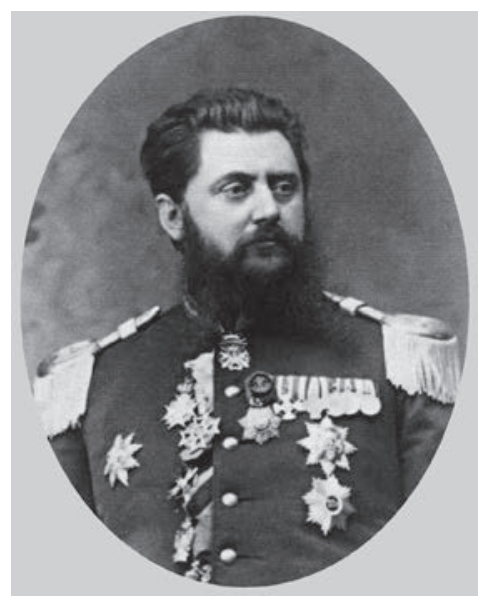

Слика 7. Санитетски пуковник др Владан Ђорђевић гимнастици онолика пажња, колико телесно развиће заслужује према убеђењу свију савремених педагога и лекара, једино с тога што за грану наставе нисмо имали скоро никаквог наставничког персонала. Али баш зато држим да би крајње време било размислити о начину како да се дође до потребног броја добрих учитеља гимнастике...“

„Има неумољивих доказа да наша раса, из разних хигијенских одношаја свога живота почиње кржљавати у своме телесном узрасту и у својој телесној снази. Један поглед на ма који батаљон наше стајаће војске, који се саставља од регрута из целе државе, довољан је да покаже какове су последице од те телесне кржљавости за умну и материјалну будућност нашега народа, није ни мало потребно на овоме месту излагати. И за вас је цело као и за мене јасно, да држава треба овоме опадању наше народне снаге да поклони најозбљнију своју пажњу, за то сам ево и узео слободу предложити вам да заједнички, сваки са гледишта свог ресора у државној администрацији, порадимо колико можемо, да се унапреди здравље и телесна снага нашега народа“. - из йисма министира Милуичина Гарашанина минисӣру йросвете Сйојану Новаковићу, 13. октобра 1881.

У опширном писму, адресираном на Министарство просвете и црквених послова (13.октобра 1881), предлаже се министру Новаковићу решавање бројних важних питања за здравство, школство, 

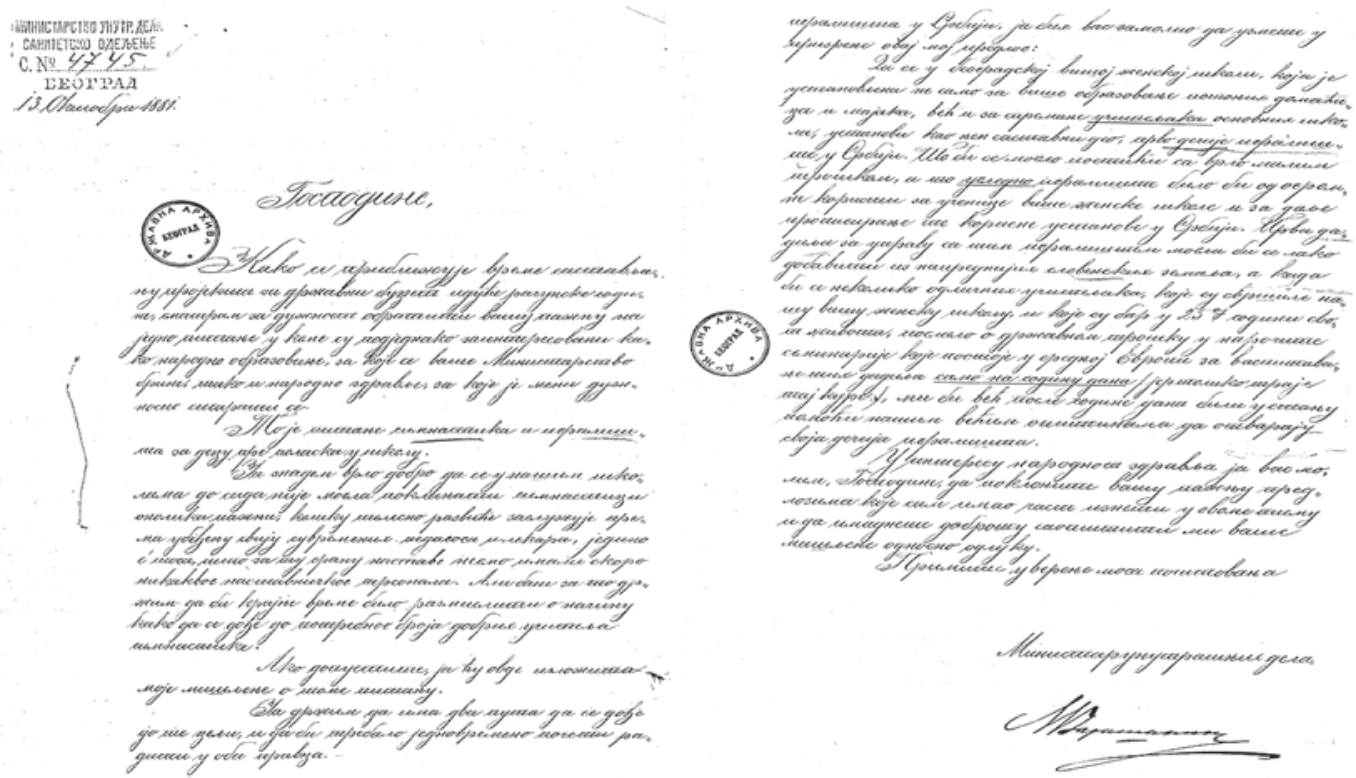

Слика 8. Писмо министра Гарашанина министру Новаковићу, прва и последња страна, 1881.

спорт и васпитање: „оснивање великог гимнастичког друштва у Београду, са што више чланова оснивача из лекарског и професорског сталежа, који би број чланова подигли на барем неколико стотина; подизање зграде за бављење гимнастиком лети и зими; спремање учитеља гимнастике за средње, а доцније и основне школе који не би смели бити аматери и дилетанти, већ темељно и нарочито образовани стручњаци у томе послу; спремање гимнастичара који ће, мало по мало, успети да у својој вароши и варошици оснују гимнастичку дружину, а ове би стојећи све у непрекидној вези са централним гимнастичким друштвом у Београду саставиле једну огромну мрежу установа, које би, избегавајући свако бесциљно пеливанисање, и радећи по једном заједничком хигијенском плану, за неколико година знатно унапредиле ниво телеснога здравља у Србији; издвајање извесне суме у буџету министарства за неколико интелигентних, здравих и са одличним успехом питомаца гимнастичке струке ради школовања за професоре гимнастике у Штокхолму; законско изравнавање професора гимнастике са професорима других дисциплина; отварање игралишта за децу предшколског узраста - „Фребелово дечје игралиште, познато и као „Киндергарден“, прво у Вишој женској школи; слање неколико одличних учитељица о државном трошку на нарочити једногодишњи семинар у средњој Европи...“ (Архив Србије, МПс-п, 1881).
Иако је министар Новаковић имао другачије мишљење по бројним питањима, подржао је предлог о оснивању гимнастичког друштва, јер је идеја у јавности већ ухватила корен. Др Владан Ђорђевић био је у то време цењен и као политичар и књижевник и лако добија пристанак учитеља гимнастике Стеве Тодоровића, Ферда Михоковића и Љубомира Илића да ће у почетку предавати гимнастику бесплатно. Пошто је Михоковић неко време био болестан, друштву је приступио др Драгиша Станојевић (Трујић 1976).

Да одушевљење не би утихнуло, одмах окупља угледне Београђане у кафани „Српска круна“ (20. октобар 1881) - 33 потписника загрејана овом узвишеном и корисном по народ идејом, и позива их за оснивачки одбор, међу њима су познати др Лаза Костић, Милан Ђ. Милићевић, др Лаза К. Лазаревић, Милорад Шапчанин, Мита Ценић, као и вође Либералне, Напредне и Радикалне странке Радивој Милојковић, Милутин Гарашанин и Никола Пашић. Одлука о оснивању Беоіраgскоі̄ gpy-

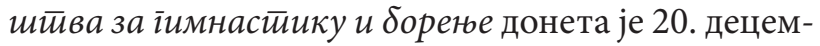

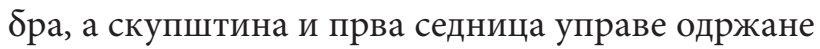
су у недељу 3. јануара 1882. у „Српској круни“. За председника је изабран некадашњи министар, генерал Тихомир Николић, за потпредседника Стеван Тодоровић, а „управни чланови“, поред друге господе, постали су др Владан Ђорђевић и др Лаза Костић (Српске новине, 1882). Тиме 
је обновљена делатност Прве срйске gружине за іимнасиичку и борене, поникле из Тодоровићеве Сликарске школе (1857).

Првих дана по оснивању друштва већ је основан курс за децу и „женскиње“ и курс за малу женску и мушку децу од 6 до 10 година. Курс за женске чланове водила је учитељица гимнастике Више женске школе Станислава Вишекова (од фебруара 1882), а мушки чланови друштва су код Делијске чесме вежбали борење са сабљом од јула 1882. (Трујић, 1976; Петровић, 1983)“. После два и по месеца др Владан Ђорђевић прихватио је да замени на функцији председника Друштва генерала Николића, и у следећих десет година два пута биће председник (1882-1884. и 1889-1891) и у једном мандату потпредседник (1886-1888) (Илић и Мијатовић, 2006).

Ђорђевић и потпредседник Стева Тодоровић потписали су Уредбу (Правила) о раду Друштва којима су у пет тачака одређени циљ и програм рада са задацима (Илић и Мијатовић, 2006):

- да се „систематичним телесним вежбањем , излетима, маршевима и борењем мачевима и 'плајвазима' унапређује телесна снага и здравље много-поштованих чланова“;

- да се „стара за оснивање подобних дружина у народу, које би поред неговања телесне снаге, шириле свест народне заједнице“;

- „да приређује нарочита гимнастичка предавања и практична вежбања за све сталеже 'обојег' пола“;

- да се „при свечаним вежбањима нарочито обраћа пажња на народне игре за снажење тела“, и

- „да о свом трошку спрема учитеље гимнастике“.

Друштво постаје амбициозно и програмски и институционално, па се промовише гимнастика и помаже оснивање гимнастичких друштава по градовима Краљевине Србије: у Зајечару и Шапцу 1882, Смедереву 1885, Крагујевцу... (Вукашиновић и сар. 2015). Нимало лак подухват увођења вежбања Ђорђевић је повезао са пословима у цивилном санитету. „Српска младеж постаје све кржљавија, а што се види и на регрутима из целе државе“ - писао је и говорио приликом агитација оснивања гимнастичких друштава ван Београда. Иако на високом положају, био је предан и упоран у овој мисији, познат и по томе да му се никада није догодило да било кога остави ठез одговора.
Таква ревност и учтивост покретале су спортске ентузијасте (исто).

Ђорђевић је омогућио да се у недељном листу „Народно здравље“ објављују активности, информације и размена искустава гимнастичара. Београђани су слали „Упутства“, „Уредбе“ и „Правила вежбаонице“, образац чланске карте са евиденцијом долазака, што се сматрало основом успостављања организације. У овом листу написао је чланак "Гимнастика мале деце" (1881). Поред моралне и стручне помоћи у заједничким јавним вежठачким наступима, друштвима су помагали и материјално, набавком реквизита (Вукашиновић, 2016). Написао је и “Дечија игралишта (“Фребелове баште”), ову тему предавао је на другој годишњој забави Друштва у Народном позоришту (1883), том пригодом изводила се и комедија “Женске сузе и гимнастика“, коју је написао годину раније (Суботић, 1910).

Временом, из гимнастичког „турнерског“ система вежбања изнедриле су се две гимнастичке струје - „Соко“ и „Душан Силни“, а Ђорђевић, коме је сметало њихово велико ривалство, штетно по стање и развој гимнастике у Србији, иако се повукао, није престао да помаже гимнастику, касније и соколство. Значај Ђорђевићевог доприноса развоју гимнастике и соколства огроман је.

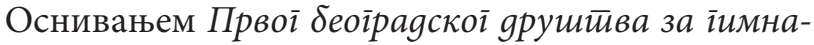

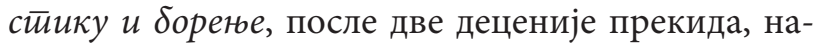
стављено је организовано телесно вежбање, оснивање сличних грађанских гимнастичких организација широм Србије, те васпитавање чланства о потреби вежбања, усавршавање стручних кадрова. Тако су стварани услови да гимнастичка организација у једном тренутку спремно прихвати чешки соколски систем вежбања, што ће његовим даљим развојем бити добра основа за појаву и развој модерног спорта у Србији (Вукашиновић, 2016a).

Време је убрзо показало да је Ђорђевић визионарски предвидео значајну улогу грађанских гимнастичких друштава у развоју и популаризацији физичке културе - телесног вежбања грађанства, школског физичког васпитања и спорта у Србији. За доприносе у развоју телесног вежбања у Краљевини Србији, соколи Краљевине Југославије доделили су му статус почасног члана утемељивача (1938) и назвали „оцем гимнастичких друштава и пиониром соколства“ (Драгић, 1938). 


\section{ВЛАДАН ЂОРЂЕВИЋ, ВИЗИОНАР НАЦИОНАЛНЕ, ИСТОЧНЕ И ЗАПАДНЕ ПРОВЕНИЈЕНЦИЈЕ}

Санитетски пуковник, доктор Владан Ђорђевић, први школовани српски хирург, академик, дипломата, председник владе, министар, политичар, научник, књижевник, историчар, начелник цивилног и војног санитета, оснивач Српског лекарског друштва, Црвеног крста, нишке Војне болнице, утемељивач васпитно-образовних и спортских институција, својом плодоносном мисијом подарио је велика дела Краљевини Србији крајем 19. и почетком 20. века. Био је визионар и стваралац неисцрпне животне снаге и духа, ерудита испред времена у ком је живео. Биран је за редовног, дописног или почасног члана у 17 медицинских, историјских, књижевних и дипломатских друштава, у Србији, Немачкој, Француској, Белгији, Швајцарској, Шпанији, Русији и Грчкој. Са 25 година изабран је у Српском ученом друштву за редовног члана Одбора за науке јестаственичке и математичке и Одбора философског. За дописног члана Српске краљевске академије философских наука, биран је 1888, а за "правог" (редовног) 1892. У попису одликовања имао је 29 медаља, ордена, ратних споменица, уручених од европских царева, краљева и академија.

Усамљен, стар и болестан Владан Ђорђевић је преминуо 31. августа 1930. у Бадену. Држава је овог великана, који је на свом животном путу верно следио своју страст за радом и истином, поштујући себе и свој народ, скромно сахранила, без публицитета и помпе. А Београђани су га брзо заборавили, како то иначе бива у нас, нису му се одужили ни називом улице или сокачета.

\section{ЛИТЕРАТУРА}

1. Архив Србије, МПс-п, 1881. 18, 110: Писма нинистиру Гарашанину йовоgом иницијатииве оснивата Гимнасииччкої друшитва. Београд

2. Архив Србије: Влаgан Ђорђевић, тични фоня, 1969. 1844-1930: 27, 63, 87, 89, 94, 106, 178, 181 185. Београд

3. Биографије нових академика, Д-р Владан Ђорђевић. Годишњак Срйске кратевске акаgемије 8, 1895: 117-120, 121-124, 132-133.

4. Биографије академи-ка, Д-р Владан Ђорђе-

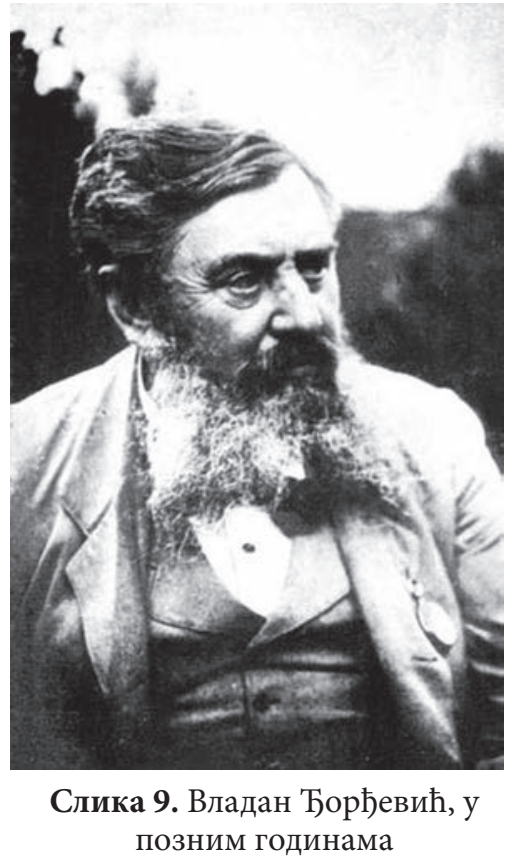

О Владану Ђорђевићу, др Војислав Суботић је написао: „Ја сам се вазда дивио његовом великом уму, генијалности, неуморном труду, вредноћи и издржљивости његовој у раду“. [...] „био је силан и моћан, нападан и нападао је, поштован а и омрзнут, силан на перу, моћан у говору - а што је главно - целог века поштен човек“. (15. фебруара 1910). А сам је Владан Ђорђевић, на последњим страницама књиге „Министар у апсу“, написао:

„Тамновање сам доживео као прву доколицу у животу“ $[\ldots]$ „У новом животу који би отпочео, апсолутно ништа не би мењао, и тај нови живот живео би исто овако, као овај до сада“. [...] „Живот ठез свега тога не би ठио живот него Баруштина“"(1909).

вић. Годишғьк Срйске краљевске акаgемије 21, 1908: 423-425.

5. Вукашиновић, В. (2016). Гимнастиика и соколстиво у Србији gо 1941. іолине, великани срйске іимнастине и соколстива. Београд: Универзитет у Београду, Факултет спорта и физичког васпитања.

6. Вукашиновић, В. (2016а). Грађанска гимнастичка друштва и спорт у Краљевини Србији. Физичка кулимура (70)1, 23-33. 
7. Вукашиновић, В. (2017). Стеван Тодоровић, живот и дело вежбача, уметника, просветитеља и зачетника организованог спорта у Србији. Физичка кулйура (71)2, 118-126.

8. Вукашиновић, В., Мијатовић, С., Величковић, С. и Шиљак, В. (2015). Прилог проучавању оснивања друштава за гимнастику и борење у Краљевини Србији. Физичка кулитура, 69(1). 44-50.

9. Драгић, М. (1938). Др. Владан Ђорђевић, пионир Соколства у Србији. Соколски іласник, Савез С окола Краљевине Југославије, 16. децембар; ИХ, 46:1. Београд.

10. Ђорђевић, В. (1909). Голі̄ой, роман из балканскоі̄ живот̄а. Београд: изд. И. Даничића, „Штампа“.

11. Ђорђевић, В. (1905). Крај јеgне gинастиије, йрилози за истиорију Србије, 1-4. Београд: штампарија Д. Димитријевић.

12. Ђорђевић, В. (1909). Министиар у Айсу. Београд: Штампарија Ст. М. Ивковића и комп.

13. Ђорђевић, В. (1927). Усйомене, кулииурне скиие из gруїе йоловине 19. века 1. Нови Сад: књижара „Славија“.

14. Илић, С., и Мијатовић, С. (2006). Истиорија физичке кулитуре Кнежевине и Кратевине Ср-

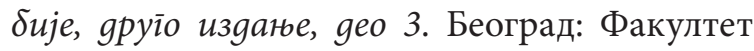
физичке културе Универзитета у Београду.

15. Јовановић, Б. (1957). Поводом стогодишњице организованог физичког васпитања у Србији. Физичка кулитура 7-8, 326-332.

16. Јовановић, С. (1929). Влаgа Алексанgра Обреновића, 1. Београд: књижарница Г. Кона.

17. Јовановић, С. (1935). Влаgа Алексанgра Обреновића, 2. Београд: књижарница Г. Кона.

18. Јовановић, С. (1926).Влаgа Милана Обренови$\hbar a, 1$. Београд: књижарница Г. Кона.
19. Јовановић, С. (1925). Ђорђевић Владан др. У: Станојевић С, уредник. Нароgна енциклойеguja, 1. Загреб: Библиографски завод; 693.

20. Лукић, М. http://miljalukic.blogspot.com /2010/09/ vladan-djordjevic-beograd-21.html (Ту и тамо) - Владан Ђорђевић - Човек за сва времена. Приступљено 5.082015.

21. Петровић, В. Ј. (1983). Физичка култура до 1941. год. У Социјалистиччка рейублика Србиja, II йом, ур. М. Малетић. Београд: Књижевне новине.

22. Рајић, С. (2010). „Историјска читанка - о др Владану Ђорђевићу“, фељьйон, Вечерње новости.

23. Савић, 3. (2014). Историјски приступ проучавања живота и дела санитетског резервног мајора др Ђорђа Михајловића. Ацйа меgица Меgианае; 53(2): 58.

24. Слапшак, С. (1988). Влаgан Ђорђевић: јеgна

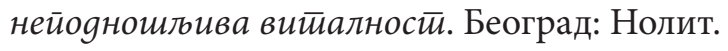

25. Срйске новине, 5.01.1882. и 3.04.1882.

26. Суботић, В. (1910). Докйор Влаgан Ђорђевић, йеgесейоїодишғьица књижевноі раgа. Београд: Нова штампарија С. Раденковић.

27. Трујић, Никодије. (1976). Физичка кулитура у школама Србије у 19. веку. Београд: Комисија за историју, архив и музеј физичке културе Србије.

28. Чоловић Р. (2007). Допринос др Владана Ђорђевића стручним састанцима српског лекарског друштва. Срйски архив за иелокуйно лекарстиво 135(11-12): 689-95.

29. Ћоровић, В. (2010). Истиорија Срба. Београд: Макибоок. 


\title{
VLADAN DJORDJEVIC, VIDA Y OBRA DEL ATLETA, CIENTÍFICO, POLÍTICO, ESCRITOR, FUNDADOR DE LA GIMNASIA SERBIA Y DEL MOVIMIENTO SOKOL
}

\begin{abstract}
Resumen
Vladan Djordjevic pertenecía a una generación de los estudiantes del Liceo de Belgrado, que posteriormente llegaron a ser influyentes trabajadores científicos, culturales, sociales y políticos. Una actividad sin descanso en la vida pública social de Belgrado y del Reino de Serbia, el desempeño destacado de los oficios estatales y las funciones diplomáticas, una imponente obra creativa en medicina, historia y literatura, ponen a Vladan Djordjevic en el mismo tope de las personalidades importantes de la historia de Serbia. Además de los méritos en trazar la vida social, cultural, científica y política de Serbia ha dado una enorme contribución al desarrollo de la cultura física en el Reino de Serbia a finales del siglo 19 y al principio del siglo 20. Como estudiante del Liceo de Belgrado, practicando gimnasia y artes marciales, Djordjevic se hizo amante de ejercicios físicos y se dio cuenta de su importancia para la salud y fortalecimiento del espíritu y se les adjuntó. Djordjevic no podía olvidar este inicio de gimnasia organizada y veinte cuatro años después, como un médico respetable y jefe del Departamento de Sanidad en el Ministerio de Asuntos Interiores, llega a ser el autor de la idea de fundar „una gran sociedad gimnástica en Belgrado con las sucursales por toda Serbia“. El desarrollo de la gimnasia en Serbia condicionó dentro de poco la aceptación del movimiento Sokol y la aparición del deporte moderno. El objetivo del trabajo es estudiar y elaborar, aplicando el metido histórico, los documentos auténticos de 1895, 1908, 1910, 1925-1927, 1938, etc., en general desconocidos y no disponibles al público en general y profesional que alumbran las contribuciones multifacéticas del doctor Vladan Djordjevic y sobre todo en la cultura física.
\end{abstract}

Palabras claves: VLADAN DJORDJEVIC / CULTURA FÍSICA / MEDICINA / LITERATURA / HISTORIA / POLÍTICA / SERBIA

Примљен: 01.04.2018

Прихваћен: 12.05.2018 